Original paper

\title{
Temporal relationships between Mg-K mafic magmatism and catastrophic melting of the Variscan crust in the southern part of Velay Complex (Massif Central, France)
}

\author{
Simon COUZINIÉ $1,2,3 *$, Jean-François MOYEN ${ }^{2,3}$, Arnaud VILLAROS ${ }^{4,5,6}$, Jean-Louis PAQUETTE², \\ Jane H. SCARROW ${ }^{7}$, Christian MARIGNAC ${ }^{8}$ \\ ${ }^{1}$ École Normale Supérieure de Lyon, 69364 Lyon Cedex 7, France; simon.couzinie@ens-lyon.org \\ ${ }^{2}$ Laboratoire Magmas et Volcans, UMR 6524 CNRS, Université Blaise Pascal, Rue Kessler, 63038 Clermont-Ferrand, France \\ ${ }^{3}$ Université Jean Monnet, 23 rue du Dr Paul Michelon, 42023 Saint-Étienne, France \\ ${ }^{4}$ ISTO, UMR 7327, Univ. Orleans, F-45071 Orleans, France \\ ${ }^{5}$ ISTO, UMR 7327, CNRS, F-45071 Orleans, France \\ ${ }^{6}$ ISTO, UMR 7327, BRGM, F-45060 Orleans, France \\ ${ }^{7}$ Department of Mineralogy and Petrology, Campus Fuentenueva, University of Granada, 18002 Granada, Spain \\ ${ }^{8}$ UMR 7359 Géoressources, École des Mines, Campus ARTEM, CS 14 234, 54042 Nancy Cedex, France \\ ${ }^{*}$ Corresponding author
}

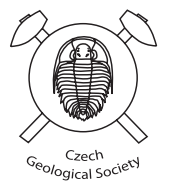

\begin{abstract}
$\mathrm{Mg}-\mathrm{K}$ mafic intrusive rocks are commonly observed during the late stages of the evolution of orogenic belts. The Variscan French Massif Central has many outcrops of these rocks, locally called vaugnerites. Such magmas have a mantle-derived origin and therefore allow discussion of the role of mantle melting and crust-mantle interactions during late-orogenic processes. In the Southern Velay area of the French Massif Central, LA-ICPMS U-Pb dating on zircons and monazites from three vaugnerites and four coeval granites reveals that the two igneous suites formed simultaneously, at c. $305 \mathrm{Ma}$. This major igneous event followed after an early, protracted melting stage that lasted for 20-30 My and generated migmatites, but the melt was not extracted efficiently and therefore no granite plutons were formed. This demonstrates that widespread crustal anatexis, melt extraction and granite production were synchronous with the intrusion of vaugneritic mantle-derived melts in the crust. The rapid heating and subsequent melting of the crust led to upward flow of partially molten rocks, doming and collapse of the belt.
\end{abstract}

Keywords: vaugnerite, granite, U-Pb geochronology, Variscan, French Massif Central

Received: 17 May 2013; accepted: 19 November 2013; handling editor: M. Štemprok

The online version of this article (doi: 10.3190/jgeosci.155) contains supplementary electronic material.

\section{Introduction}

The $\mathrm{Mg}-\mathrm{K}$ mafic magmatic suites correspond to a highly heterogeneous group of igneous rocks closely associated with post-collisional granitic suites (see review in Bonin 2004). Their relative scarcity but systematic occurrence throughout most orogens makes them particularly useful as markers to understand the evolution of the lithosphere at the end of major orogenic episodes. In the European Variscan belt for instance, various types of such rocks are diversely known as "vaugnerites" in the French Massif Central (Sabatier 1980; Michon 1987; Sabatier 1991), "durbachites" in the Vosges (Gagny 1979), Schwarzwald (Kober and Lippolt 1985) and Bohemian Massif (Holub 1997a, b; Janoušek et al. 1997; Gerdes et al. 2000; Kotková et al. 2003, 2010), shoshonites, appinites and lamprophyres in central Spain (Castro et al. 2003; Perini et al. 2004; Scarrow et al. 2008, 2009; Molina et al. 2012). Older examples include the Caledonian appinites (Fowler 1988; Bowes and Košler 1993; Fowler et al. 2008; Mur- phy 2013), and even the Archaean "sanukitoids" (Martin et al. 2010; Fowler and Rollinson 2012). Given that a mantle source has been invoked in the petrogenesis of all the above examples, these rocks can be used to address the question of mantle input, through mass and/or heat transfer, during crustal melting and granite production.

The vaugnerites of the French Massif Central are $\mathrm{Mg}-\mathrm{K}$-rich biotite-rich diorites. Although many petrological types are known (see review in Sabatier 1991), all examples share the same key characteristics: major minerals are biotite, plagioclase, hornblende, interstitial quartz and $\mathrm{K}$-feldspar, minor clinopyroxene, and rare orthopyroxene (Montel 1988); accessory phases such as apatite, zircon, allanite and titanite are abundant (Montel and Weisbrod 1986). Vaugnerites usually crop out as intrusive bodies or enclaves in coeval felsic rocks (Sabatier 1991). They are well-exposed at the southern border of the Velay Complex, a large anatectic dome of migmatites cored by a heterogeneous, cordierite-bearing, S-type granite (Ledru et al. 2001). 
The aim of this study is to constrain the temporal relationships between crustal melting and $\mathrm{Mg}-\mathrm{K}$ mafic magmatism in the southern Velay, on the basis of field observations of vaugnerites coupled with $\mathrm{U}-\mathrm{Pb}$ dating on zircon and monazite. Determining the chronological framework of the melting events allows us to constrain the crustal evolution in the region at the end of the Variscan orogeny.

\section{Geological setting}

The Variscan belt of Europe formed between c. 400 and $280 \mathrm{Ma}$ as a result of the convergence between Laurussia, Gondwana and intervening microplates (Matte 1986; Edel 2001; Guy et al. 2011; Kroner et al. 2013). The French Massif Central is a Gondwana-derived microcontinent (Melleton et al. 2010) accreted to Laurussia in Devonian to Carboniferous times (e.g. von Raumer et al. 2003). A large portion of the Eastern French Massif Central is occupied by the Velay Complex, a c. 100 by $100 \mathrm{~km}$ migmatite dome (Lagarde et al. 1994; Ledru et al. 2001). A large volume of peraluminous granite forms its core (Williamson et al. 1992; Lagarde et al. 1994; Downes et al. 1997; Ledru et al. 2001), and cuts across the Early Carboniferous nappe stack (Faure et al. 2009 and references therein). The Southern Velay area experienced a polymetamorphic evolution during the Variscan orogeny, described as a succession of four major tectono-metamorphic events (Marignac et al. 1980; Montel et al. 1992). They affected two contrasting lithologies (Fig. 1): the Cambrian "Ardèchois" orthogneisses (R'Kha Chaham et al. 1990; Alexandre 2007; Melleton et al. 2010); and the possibly Precambrian to Ordovician "Cévenol" metasediments (Pin and Marini 1993; Caron 1994; Roger et al. 2004; Melleton et al. 2010).

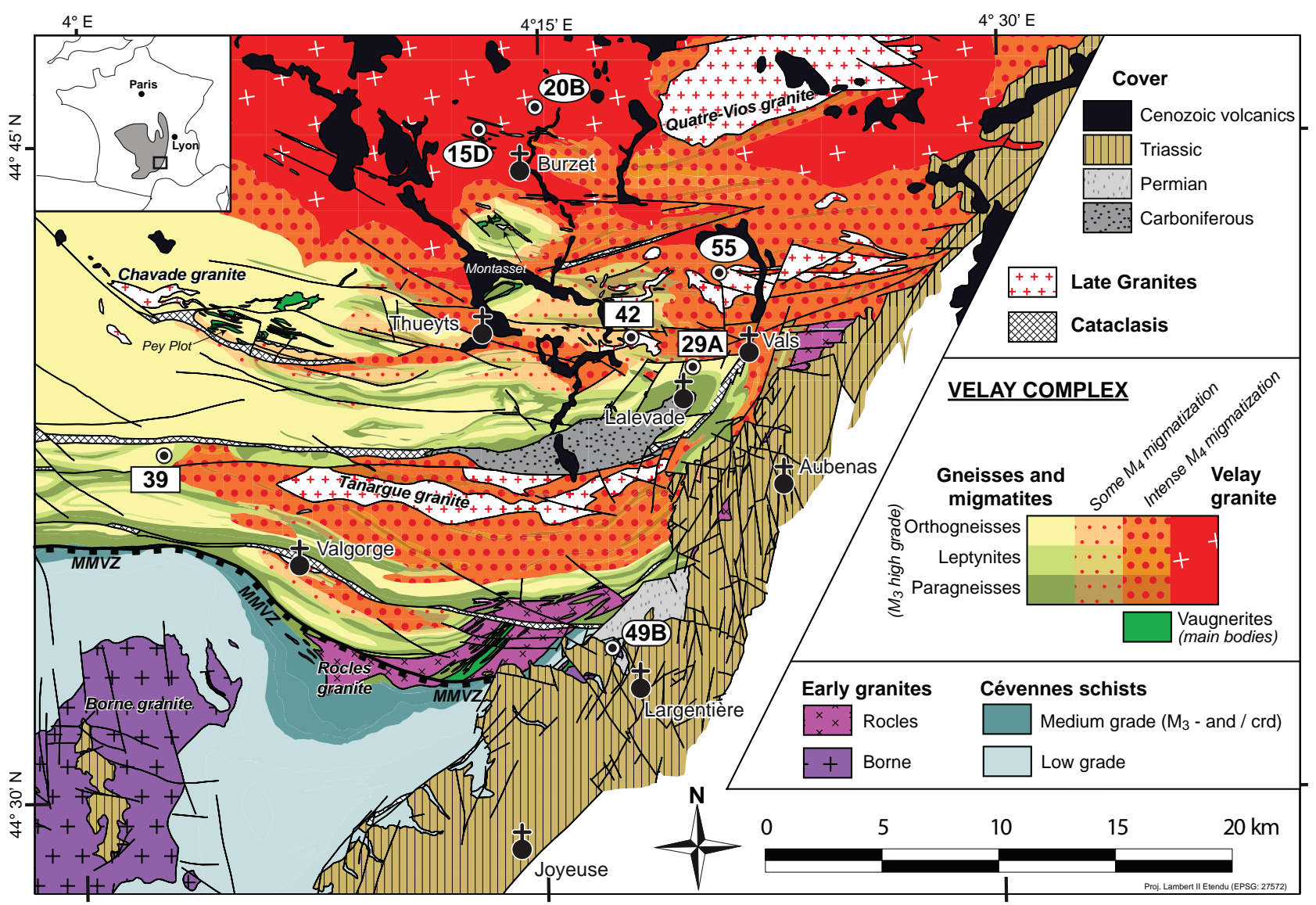

Fig. 1 Geological map of the Southern Velay region, adapted from Weisbrod (1970); 1/50 000 geological maps; and unpublished maps (ENSG mapping camps, 1970-1990s). Location map in inset, showing the study area in the south-eastern portion of the Variscan Massif Central (grey). The $\mathrm{M}_{4}$ overprint is shown in orange (with red dots), superimposed on the yellow/green depicting the pre- $\mathrm{M}_{4}$ lithologies ( $\mathrm{M}_{3}$ high-grade ortho- and paragneisses); the paragneisses of the "Cévenole" Series are the high-grade equivalents of the Cévennes schists, south of the MMVZ (Mylonitic Metamorphic Vellave Zone from Bouilhol et al. 2006). Only the largest vaugnerite bodies are shown here (in the Rocles granite, and at Pey Plot East of Chavade Pluton, cf. Ait Malek 1997); innumerable, 1 to $10 \mathrm{~m}$ bodies are found throughout the area. The location of geochronology samples is indicated on the map; peraluminous granite samples are ellipses (15D Peyron, 20B Velay, 55 Tanargue), vaugnerites rectangles (39 Loubaresse, 42 Meyras, 29A Pont-de-Bayzan) and metaluminous granites rectangles with rounded edges (49B Largentière). The Largentière granite is an outlier of the larger Borne Complex, to the west. 
- $\mathrm{D}_{1}$ is inferred from relicts in high-grade (eclogitic) units, mostly north and west of our study area (Lardeaux et al. 2001; Berger et al. 2010); the eclogitic metamorphism $\left(\mathrm{M}_{1}\right)$ is dated (U-Pb on zircons) at $c$. 410-430 Ma in various outcrops of the Massif Central (Pin and Lancelot 1982; Ducrot et al. 1983; Paquette et al. 1995; Berger et al. 2010).

- $\mathrm{D}_{2}$ collisional nappe stacking linked to $\mathrm{N}-\mathrm{S}$ compression (Marignac et al. 1980) caused the regional foliation. This event was associated with a syn-collisional MP-MT Barrovian metamorphism $\left(\mathrm{M}_{2}\right)$. Syn-metamorphic shearing has been dated at around 340-335 $\mathrm{Ma}\left({ }^{40} \mathrm{Ar}-{ }^{39} \mathrm{Ar}\right.$ on biotite and amphibole), both south (Cévennes: Caron 1994) and north (Lyonnais: Costa and Rey 1995) of our study area.

- $\mathrm{D}_{3}$ corresponds to NW-SE extension (Faure et al. 2009) associated with a LP-HT metamorphism $M_{3}$ that reached partial melting conditions with biotite remaining stable: $\mathrm{T}<750{ }^{\circ} \mathrm{C}, \mathrm{P} \geq 5 \mathrm{kbar}$ (Montel et al. 1992). In the field, rocks affected by the $M_{3}$ event are cordierite-free, stromatic migmatites developed at the expense of both ortho- and paragneisses. Monazite U-Th- $\mathrm{Pb}$ (EPMA) dating of anatectic paragneisses yielded ages of $329 \pm 5$ (Be Mezeme et al. 2006) and $323 \pm 3$ Ma (Cocherie et al. 2005). However, monazite dating by ID-TIMS gave a younger age of $314 \pm 5 \mathrm{Ma}$ (Mougeot et al. 1997). A HT shear zone, the Mylonitic Metamorphic Vellave Zone (MMVZ) (Bouilhol et al. 2006), developed during the $M_{3}$ event and brought the greenschist- to amphibolite-facies Cevennes schists in contact with high-grade metamorphic rocks from the "Ardèchoise" and "Cévenole" series. According to Bouilhol et al. (2006), the MMVZ reflects the uplift of the Velay Dome, but the timing of this ascent has remained disputed and in other studies the doming was associated with the $\mathrm{M}_{4}$ event (Barbey et al. 1999; Ledru et al. 2001). The syntectonic $\left(\mathrm{D}_{3}\right)$ S-type Rocles granite (Weisbrod 1970) (Fig. 1) has been dated at 324 \pm 4 (EPMA on monazite, Be Mezeme et al. 2007).

- $\mathrm{D}_{4}$ is represented by NNE-SSW transtension. Regionally, it corresponded to the development of strike-slip shear zones such as the Sillon Houiller (Faure et al. 2009). In the northern part of the study area (Fig. 1), $\mathrm{D}_{4}$ was associated with a $\mathrm{M}_{4}$ metamorphism recording a regional temperature increase, leading to fluid-absent biotite melting in the cordierite stability field. The $\mathrm{P}-\mathrm{T}$ estimates are $760<\mathrm{T}<850^{\circ} \mathrm{C}$ and $2<\mathrm{P}<5$ kbar (Montel et al. 1992). The $\mathrm{M}_{4}$ migmatites are nebulitic to diatexitic and cordierite-bearing; it is sometimes possible to still recognize their protolith ("Ardèchois" orthogneisses or "Cévenol" paragneisses). The $\mathrm{D}_{4} / \mathrm{M}_{4}$ event was synchronous with emplacement of the main cordierite-bearing anatectic Velay granite which has been dated at $298 \pm 8(\mathrm{Rb}-\mathrm{Sr}$ whole-rock, Caen-Va- chette et al. 1982) and $301 \pm 5 \mathrm{Ma}$ (U-Pb monazite, Mougeot et al. 1997).

The age of the Borne-Largentière I-type (sub-alkaline) granitic complex (Fig. 1) is unclear. A Rb-Sr whole-rock age of $315 \pm 5$ Ma was determined by Mialhe (1980), linking it with the $\mathrm{D}_{3}$ event as proposed by Weisbrod (1970). On the other hand, two samples from the MontLozère Complex, the western part of the Borne granite wrenched by the sinistral movement of the Villefort Fault, gave TIMS zircon ages of $303 \pm 3 \mathrm{Ma}$ (Brichau et al. 2008), $307 \pm 5 \mathrm{Ma}$ and $307 \pm 11 \mathrm{Ma}$ (François 2009), i.e., closer to $\mathrm{D}_{4}$.

The whole area was affected by rapid uplift and cooling in the last stages of Variscan evolution as recorded by $\mathrm{U}-\mathrm{Pb}$ apatite ages clustering around $290 \mathrm{Ma}$ (Mougeot et al. 1997). The Velay granite and related $M_{4}$ migmatites are cross-cut by late granites belonging to two main suites, the Quatre-Vios and Tanargue granite, (Montel and Abdelghaffar 1993). The previously published Permian $\mathrm{Rb}-\mathrm{Sr}$ ages (e.g. $274 \pm 7 \mathrm{Ma}$ for a Quatre-Vios granite, Caen-Vachette et al. 1982) are now believed to reflect late isotopic disturbance: the Montasset granite (Fig. 1) yielded pristine monazites with a LA-ICP-MS age of 307 $\pm 2 \mathrm{Ma}$, and fluid-altered monazites with scattered ages suggesting reopening of the isotopic system between 270 and $290 \mathrm{Ma}$ (Didier et al. 2013).

\section{Mg-K mafic intrusive rocks relation- ships to their hosts}

Vaugnerites in the study area crop out in various settings (Fig. 2, and Electronic Appendix 1), depending on the nature of the host and its anatectic history.

\subsection{Vaugnerites in orthogneisses}

The vaugnerites intruding orthogneisses are generally meter-sized bodies (although they can occur in large swarms, such as at Pey Plot) and are fine- to mediumgrained. They form lenses that are concordant with the regional foliation of ("Ardéchois") migmatitic orthogneisses (Fig. 2a). The cores of the bodies display an isotropic, probably magmatic texture whereas the rims have a cleavage that can be attributed to emplacement-related deformation. The vaugnerite bodies are commonly surrounded by small volumes of fine-grained granites, connected with surrounding leucosomes in the gneisses and therefore probably representing melt segregated from the partially molten gneisses. Interpenetrating textures and the feathered appearance of the contacts between vaugnerites and immediately surrounding fine-grained granites demonstrate that both were molten at the same time. Thus, our favoured interpretation is that the vaugnerites 

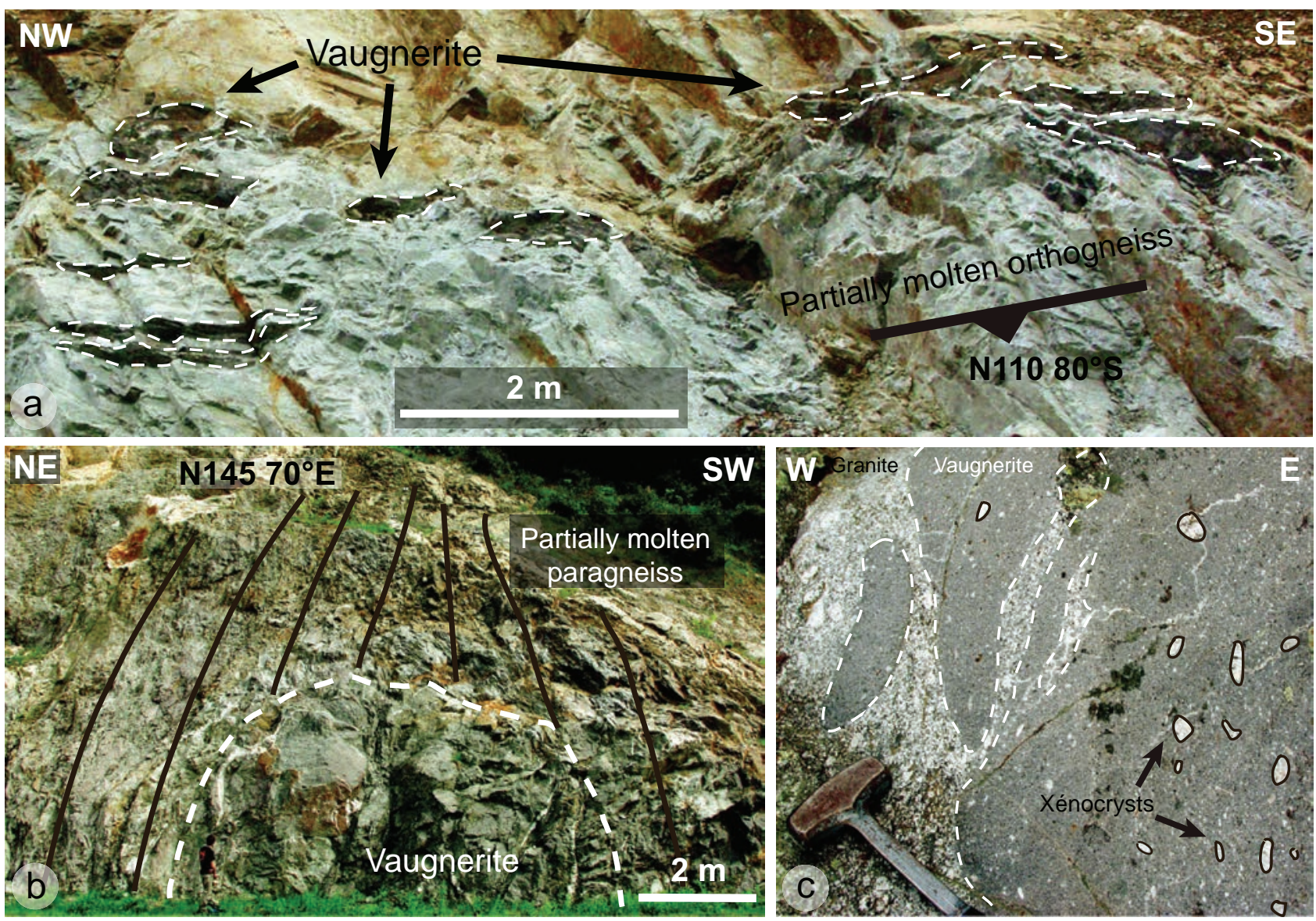

Fig. 2 Examples of vaugnerite outcrops. a - Vaugneritic lenses stretched in the foliation of migmatitic orthogneisses at Pont-de-Bayzan road cut (similar to our sample 29A). b - Intrusive vaugnerite forming a rounded enclave in diatexitic $\mathrm{M}_{4}$ paragneisses, Pont-de-Bayzan. c - Mingling textures between a vaugnerite and the Largentière granite (our sample 49B), Ligne Valley. Hammer head $12 \mathrm{~cm}$.

intruded a partially molten host, causing additional melting and/or melt segregation around the mafic bodies.

One sill of orthogneiss-hosted vaugnerite was dated by Ait Malek (1997) at Pey Plot using U-Pb TIMS on zircons; this gave an upper intercept age of $314 \pm 3 \mathrm{Ma}$.

\subsection{Vaugnerites in paragneisses}

Vaugnerites intruding metatexitic to diatexitic paragneisses are medium- to coarse-grained stocks and sills (Fig. 2b), ranging from 2 to $50 \mathrm{~m}$ in length. These intrusive bodies cut across the regional foliation (Fig. 2b) or were emplaced in low-strain domains such as axial planes of folds (Ait Malek 1997). These vaugnerites are often surrounded by felsic, plagioclase- and biotite-rich, sometimes tourmaline-bearing, pegmatoids. The outcrop shape of vaugnerites correlates with the type of migmatites in which they intrude: vaugnerites in cordierite-free, $\mathrm{M}_{3}$ migmatites (mostly metatexites) tend to form sills. This is the case for the Loubaresse sill (our sample 39, Fig. 1), previously dated by U-Pb TIMS on zircons by Ait Malek (1997) at $313 \pm 3 \mathrm{Ma}$ (upper intercept). In contrast, vaugnerites in $\mathrm{M}_{4}$ cordierite-bearing migmatites (diatexites commonly) often form rounded masses, for example at Pont-de-Bayzan (figure 2b, our sample 29A, Fig. 1) or Meyras (our sample 42, Fig. 1), which gave an age of 308 \pm 6 Ma using TIMS on zircons (Ait Malek 1997).

\subsection{Vaugnerites associated with granitic bodies}

Meter-size vaugneritic enclaves are enclosed by most granites in the area. The coeval ascent and crystallization of mafic and felsic melts are evidenced by lobate contacts and intricate shapes (Fig. 2c). Such mingling features are well-exposed north-west of Burzet where a fine-grained vaugnerite, the "Peyron diorite" (Didier et al. 1987) and a coeval biotite-bearing granite cut across the heterogeneous cordierite-bearing Velay granite (our sample $15 \mathrm{D}$, Fig. 1). Vaugnerite is also found within other late granites (such as the Tanargue granite, our sample 55, Fig. 1) or the main, heterogeneous Velay granite (sample 20B, Fig. 1). Finally, in the Ligne Valley, just north of Largentière, K-feldspar megacryst-bearing vaugnerites 
Tab. 1 Summary of samples and geochronological results. Latitude and longitude in decimal degrees, WGS84.

\begin{tabular}{|c|c|c|c|c|c|c|}
\hline \multirow{2}{*}{ Sample number } & \multicolumn{3}{|c|}{ Location } & \multirow{2}{*}{ Rock type } & \multirow{2}{*}{ Zircon magmatic age } & \multirow{2}{*}{ Monazite magmatic ag } \\
\hline & Place name & Latitude & Longitude & & & \\
\hline SGC12 15D & Peyron & 44.75042 & 4.22173 & $\begin{array}{l}\text { Late granite (unnamed granite } \\
\text { surrounding Peyron diorite) }\end{array}$ & undefined & $303.7 \pm 3.1 \mathrm{Ma}$ \\
\hline SGC12 20B & Burzet & 44.78277 & 4.25688 & Velay granite & undefined & $305.9 \pm 1.4 \mathrm{Ma}$ \\
\hline SGC12 29A & Pont de Bayzan & 44.65678 & 4.29928 & Vaugnerite & $294.4 \pm 3.9 \mathrm{Ma}$ & - \\
\hline SGC12 39 & Loubaresse & 44.60045 & 4.07053 & Vaugnerite & $307.4 \pm 1.8 \mathrm{Ma}$ & - \\
\hline SGC12 42 & Meyras & 44.67262 & 4.27383 & Vaugnerite & $305.8 \pm 2.3 \mathrm{Ma}$ & - \\
\hline SGC12 49B & Largentière & 44.5548 & 4.28738 & $\begin{array}{l}\text { Porphyritic granite } \\
\text { (Borne-Largentière) }\end{array}$ & $304.1 \pm 6.3 \mathrm{Ma}$ & - \\
\hline SGC12 55 & Chadenet & 44.69342 & 4.35143 & Late granite (Tanargue suite) & $303.9 \pm 6.5 \mathrm{Ma}$ & - \\
\hline
\end{tabular}

(resulting from mingling between ordinary vaugnerites and porphyritic granite) and the porphyritic potassic amphibole-bearing Largentière granite (Fig. 1) intrude the $\mathrm{M}_{3}$ amphibolite-facies Cévennes micaschists (Palm 1957). The Largentière granite is similar to the Borne Pluton and is regarded as an offshoot of this (Weisbrod 1970); indeed the Borne granite has very common mafic microgranular enclaves of vaugneritic composition (Mialhe 1980). The Largentière vaugnerites and granites crop out in a 400 meters long polished river bed displaying many examples of the mingling textures (Fig. 2c).

\section{U-Pb geochronology}

\subsection{Sample selection and techniques}

Seven samples were selected for LA ICP-MS geochronology (Tab. 1), with the aim of constraining the timing of vaugnerite emplacement. Therefore, we dated either vaugnerites directly or granites demonstrably coeval with the vaugnerites. Details of the field relationships and sample descriptions are given in Electronic Appendix 1. A vaugnerite (29A) stretched in the foliation of a migmatitic orthogneiss at Pont-de-Bayzan (Fig. 1) was chosen to constrain the emplacement age of the most deformed intrusions, presumed to be the oldest in the study area. The Loubaresse sill (39) and a rounded vaugnerite at Meyras (42), both corresponding to samples previously dated by Ait Malek (1997), were selected as representative of the two main types of paragneiss-hosted vaugnerites; this also allowed comparison of our LAICP-MS results with previously published TIMS data. Four granites, closely associated with vaugnerites, were also dated (Fig. 1): a heterogeneous cordierite-bearing
Velay granite (20B) displaying ductile interactions with a vaugnerite sampled north of Burzet; a biotite-cordieritebearing slightly porphyritic Tanargue granite (55) closely associated with a vaugnerite cropping out in Chadenet; a biotite-bearing Peyron granite (15D) that intruded the Velay granite and was synchronous with the "Peyron diorite" (Didier et al. 1987). Finally, biotite-bearing porphyritic Largentière granite (49B) from the Ligne Valley near Largentière was selected to date the coeval vaugneritic intrusion.

Rock samples were crushed using standard techniques (jaw crusher, disc mill) and the powder fraction $<500 \mu \mathrm{m}$ was kept. Zircons and monazites were concentrated using heavy liquids (tetrabromoethane and diiodomethane), an isodynamic Frantz separator, and then hand-picked under a binocular microscope, mounted in epoxy resin, and polished to an equatorial grain section. Analytical work was carried out in the Laboratoire Magmas et Volcans (Clermont-Ferrand). Minerals were imaged by cathodoluminescence using a Jeol JSM-5910 MEB and U-Pb analyses were conducted in situ by LA ICP-MS with an Agilent 7500ICP-MS coupled to a Resonetics M-50E $193 \mathrm{~nm}$ ArF Excimer laser system. Ablation spot diameters of $26 \mu \mathrm{m}$ and 7 $\mu \mathrm{m}$ with repetition rates of $3 \mathrm{~Hz}$ and $1 \mathrm{~Hz}$ were used for zircon and monazite, respectively. Data were corrected for $\mathrm{U}-\mathrm{Pb}$ fractionation and the mass bias by standard bracketing with repeated measurements of the GJ-1 zircon (Jackson et al. 2004) and the Moacyr monazite standards (Gasquet et al. 2010). Repeated analyses of the same standards treated as unknowns were used to control the reproducibility and accuracy of the corrections. Data reduction was carried out with the GLITTER $^{\circledR}$ software package developed by Macquarie Research Ltd. (Jackson et al. 2004). Concordia ages 
and diagrams were generated using Isoplot (Ludwig 2008). Further information on the instrumentation and the analytical technique is given in Hurai et al (2010).

\subsection{Results}

Orthogneiss-hosted vaugnerite 29A (Pont de Bayzan) yielded only a limited amount of small (around $50 \mu \mathrm{m}$ ), yellowish U-rich zircons (c. 2,000-5,000 ppm). Consequently, most analyses are highly discordant and contain large amounts of common $\mathrm{Pb}$ (Tab. 2). A regression line can be established by the combination of the oldest and least discordant points together with discordant data toward common $\mathrm{Pb}$ composition at about $300 \mathrm{Ma}$. In the Tera-Wasserburg diagram (Tera and Wasserburg 1972; Fig. 3a), the data define a trend with a lower intercept at $294 \pm 3.9$ Ma.

Samples 39 (Loubaresse) and 42 (Meyras) yielded more zircon grains (Tab. 2). The c. 300-700 ppm U contents and a larger number of data allow better definition of the crystallization ages: $307.4 \pm 1.8 \mathrm{Ma}$ for Loubaresse (39) and 305.8 $\pm 2.3 \mathrm{Ma}$ for Meyras (42) (Fig. 3b-c).

A similar, complex pattern where the analytical points are characterized by discordance associated to common $\mathrm{Pb}$ contribution is observed in the metaluminous Largentière granite 49B (Fig. 4a). As for 29A, we interpret the analytical data as defining a discordia with a lower intercept age of $304.1 \pm 6.3 \mathrm{Ma}$. The latter is similar, within error, to the ages obtained previously for the Mont-Lozère Complex (Brichau et al. 2008; François 2009), confirming that the Largentière granite is part of the Lozère-Borne Pluton, the age of which appears to be younger than the previously assumed $\mathrm{D}_{3}$ timing (Weisbrod 1970). No zircon inheritance is recorded in this granite in accordance with its metaluminous character (Bea et al. 2006).

Cathodoluminescence imaging of zircons from the peraluminous Tanargue granite (sample 55) reveals the presence of bright cores surrounded by darker rims, interpreted as inherited cores and magmatic overgrowths during granite formation. The data allow better definition of a discordia line (Fig. 4b), with a lower intercept at 303.9 $\pm 6.5 \mathrm{Ma}$, that we interpret as the crystallization age.

Both the main cordierite-bearing Velay granite (20B), and the apparently cross-cutting Peyron granite (15D), also have inherited cores and younger rims. Although some zircon analyses tend to be more concordant than in the other samples, the points scatter along the concordia (Fig. 4c and d) and do not allow definition of a proper crystallization age. On the other hand, euhedral, yellowish monazites were extracted from both samples and provided well-constrained, concordant $\mathrm{U}_{-}$ $\mathrm{Th}-\mathrm{Pb}$ ages of, respectively, $305.9 \pm 1.4$ and $303.7 \pm$ 3.1 Ma (Fig. 5).
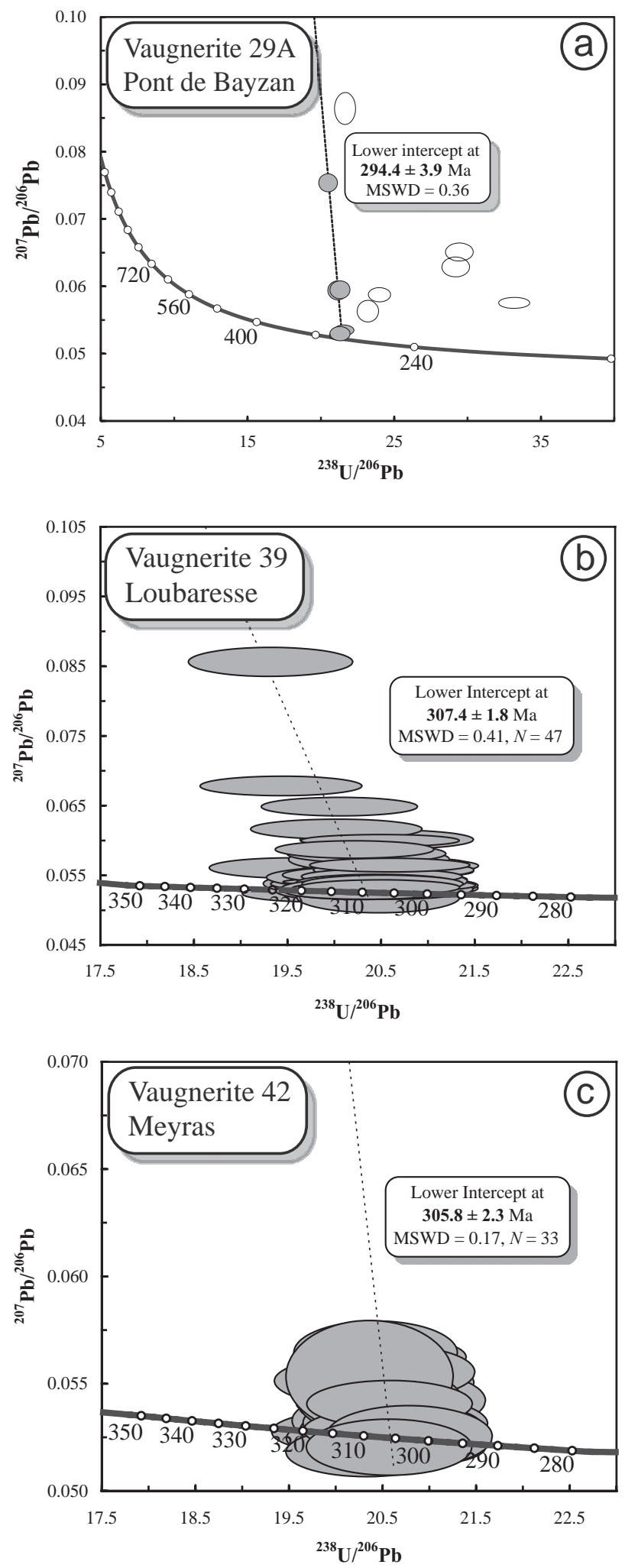

Fig. 3 Tera-Wasserburg diagrams for the three samples of vaugnerite from this study. All ellipses are represented at $2 \sigma$ level and also all ages are quoted at $2 \sigma$ level. Grey ellipses show the data used for age regression. Ages are calculated and figures plotted using Isoplot (Ludwig 2008). 

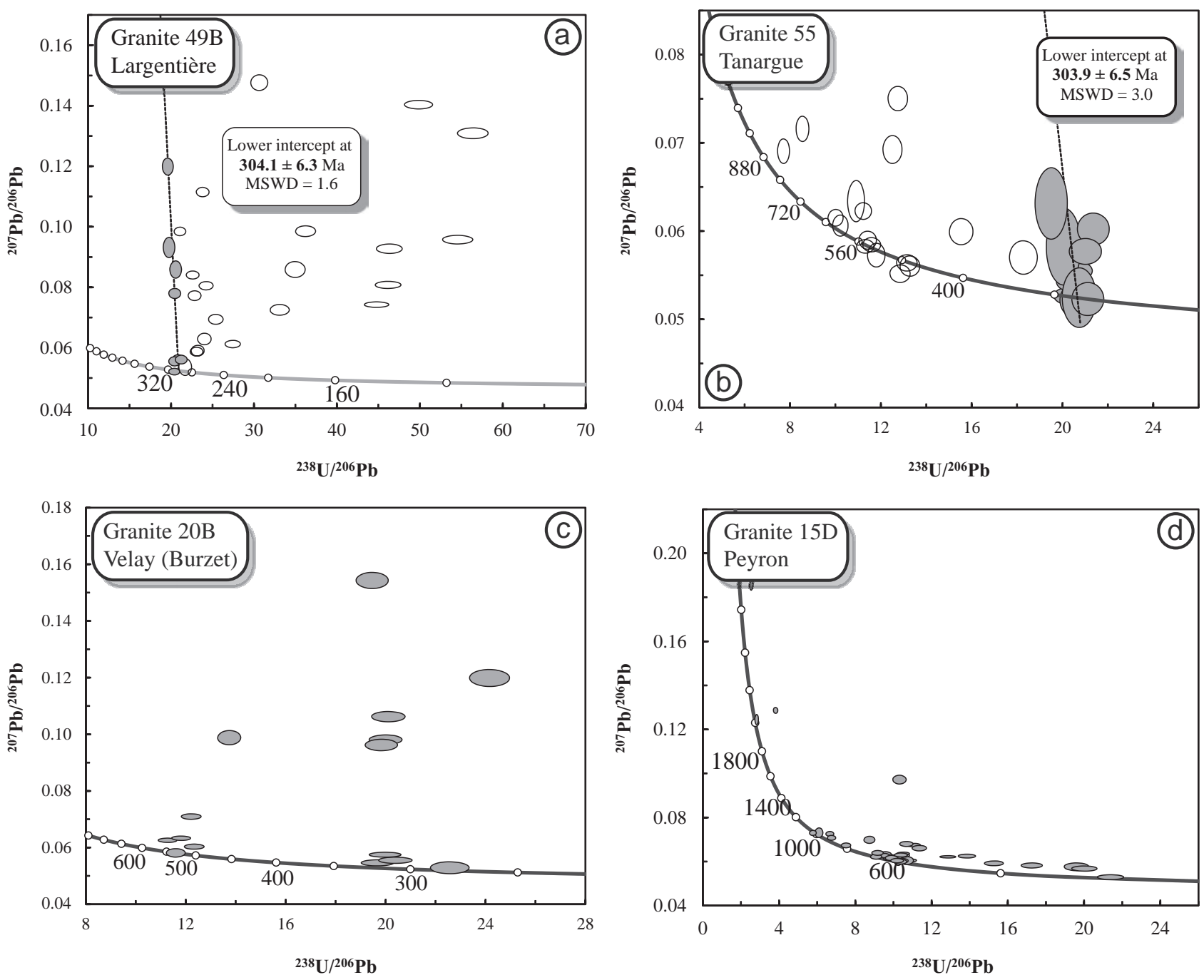

Fig. 4 Tera-Wasserburg diagrams for the four granite samples from this study. Grey ellipses show the data used for age regression.

Inherited cores range in age from 470 to $2100 \mathrm{Ma}$; the meaning of distinct inheritance patterns in each of the granitic sample is discussed in section 5.3.

\section{Discussion}

\subsection{Chronological framework of the mafic magmatism}

Vaugneritic magmatism has been dated either directly, or by using coeval felsic magmas, which allows definition of a better-constrained age. We emphasize that, in this study, the granite samples were taken in close vicinity $(<1 \mathrm{~m})$ to the "target" mafic bodies, with clear magmatic contacts (Fig. 2 and Appendix 1) and common mingling features. The ages obtained in either case are very consistent and indistinguishable within error (from $303.7 \pm 3.1$ to 307.4 $\pm 1.8 \mathrm{Ma})$.
Ages of c. 315 Ma previously obtained by ID-TIMS on vaugnerites from the Southern Velay (Ait Malek 1997) could not be reproduced in this study. We re-dated two of the bodies studied by Ait-Malek (1997), at Loubaresse (39) and Meyras (42). At Loubaresse, we found a younger age of $307.4 \pm 1.8 \mathrm{Ma}$. We believe the older $313 \pm 3 \mathrm{Ma}$ age to be an artefact of the ID-TIMS method: the dissolution of large zircon fractions may not allow unravelling of complex patterns of lead loss such as observed in the vaugnerites. Indirect confirmation of this interpretation is provided by the c. $305 \mathrm{Ma}$ age obtained by Ait Malek on coeval granites at Loubaresse. At Meyras on the other hand, our age (305.8 $\pm 2.3 \mathrm{Ma}$ ) is indistinguishable from the TIMS age (308 $\pm 6 \mathrm{Ma}$ ) of Ait Malek (1997). Collectively the evidence suggests that the emplacement of the vaugnerite-granite association occurred at $305 \mathrm{Ma}$, both at Loubaresse and Meyras - and elsewhere in the Southern Velay.

The meaning of the Permian age $(294 \pm 3.9 \mathrm{Ma})$ at Pont de Bayzan (sample 29A) is rather unclear. As a re- 
Tab. 2 LA-ICP-MS U-Pb data for monazite and zircon from seven samples. Uncertainties are given at two sigma level.

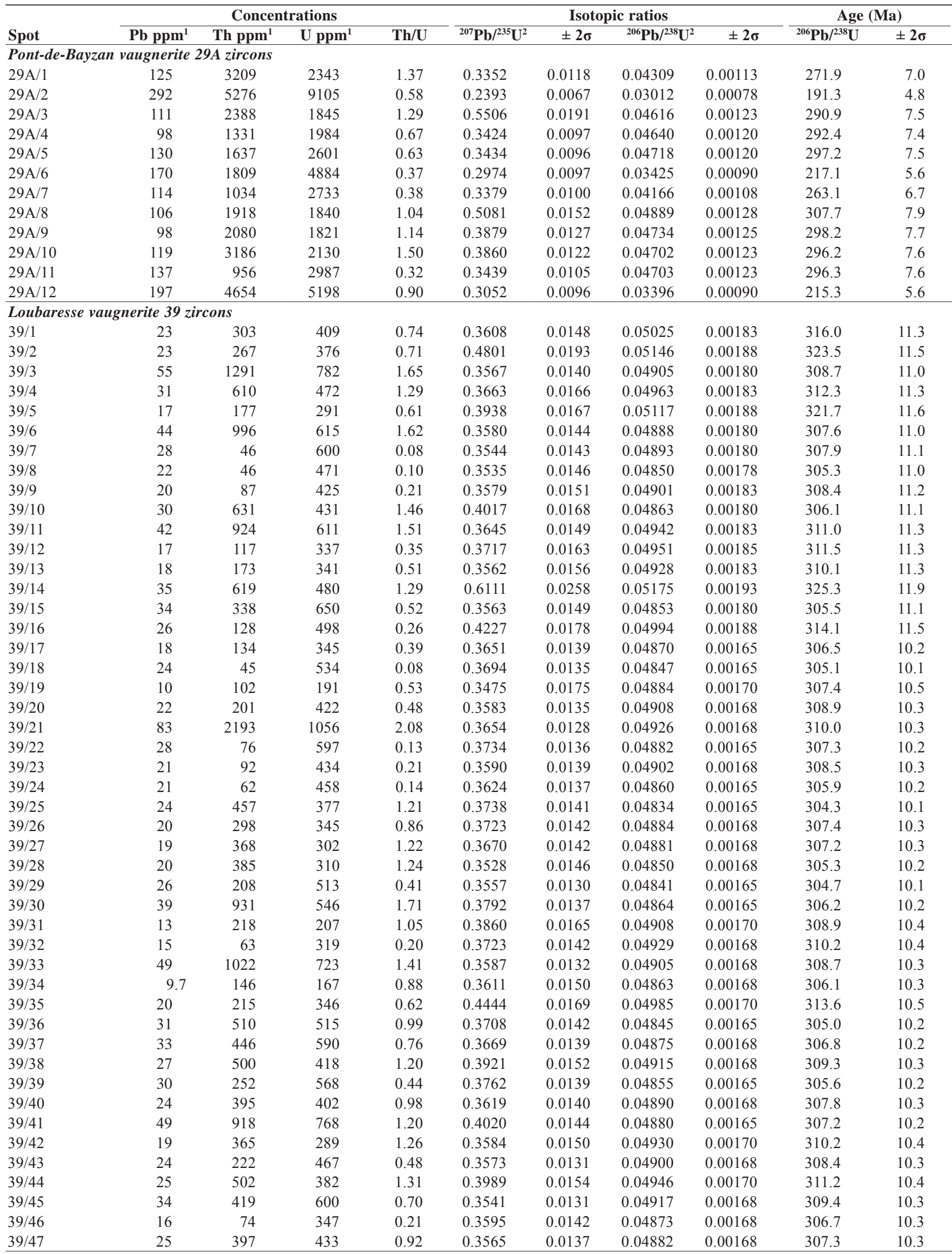


Tab. 2 Continued

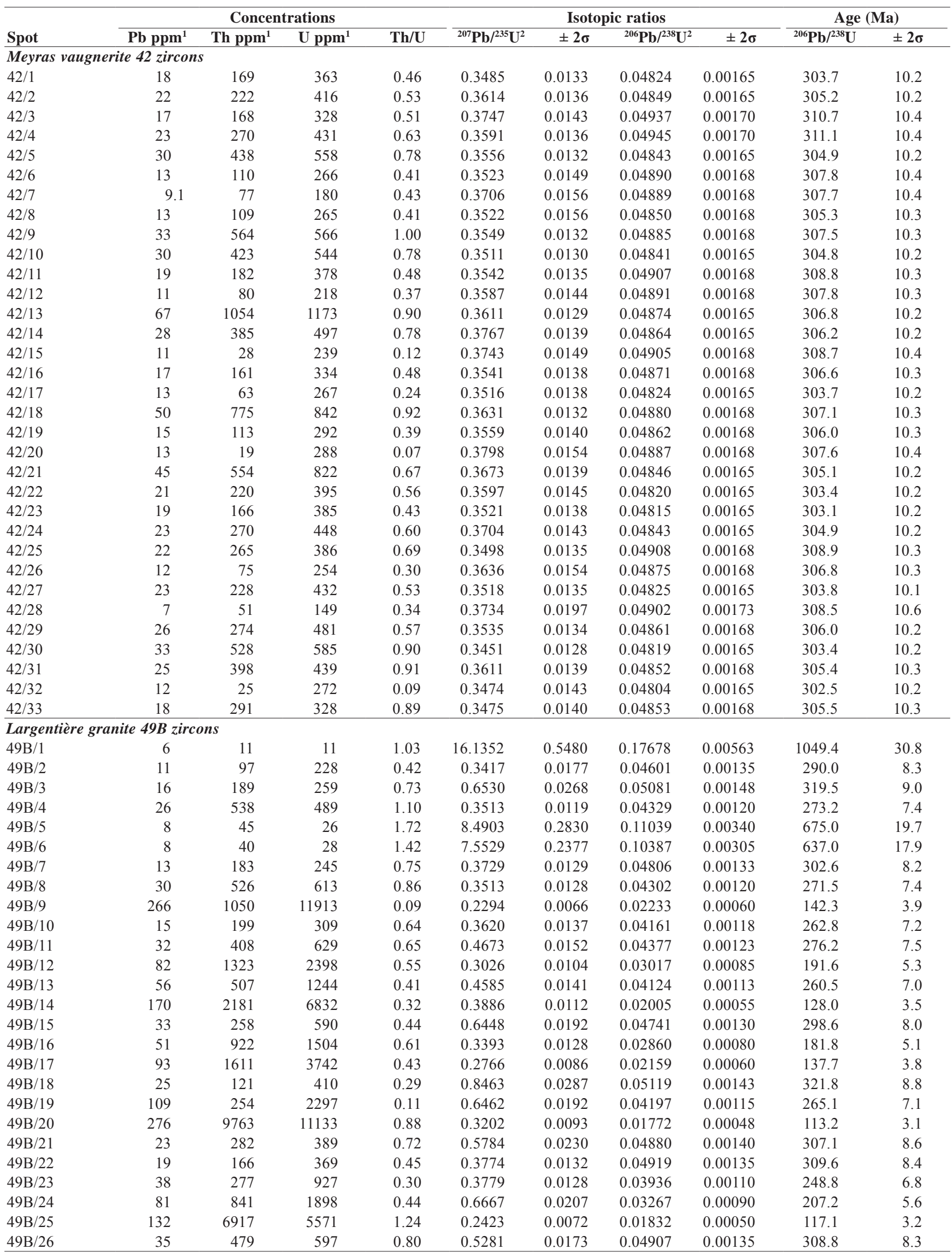


Tab. 2 Continued

\begin{tabular}{|c|c|c|c|c|c|c|c|c|c|c|}
\hline \multirow[b]{2}{*}{ Spot } & \multicolumn{4}{|c|}{ Concentrations } & \multicolumn{4}{|c|}{ Isotopic ratios } & \multicolumn{2}{|c|}{ Age (Ma) } \\
\hline & Pb ppm ${ }^{1}$ & Th ppm ${ }^{1}$ & $\mathrm{U}_{\mathrm{ppm}}{ }^{1}$ & Th/U & ${ }^{207} \mathbf{P b} /{ }^{235} \mathbf{U}^{2}$ & $\pm 2 \sigma$ & ${ }^{206} \mathrm{~Pb} /{ }^{238} \mathrm{U}^{2}$ & $\pm 2 \sigma$ & ${ }^{206} \mathrm{~Pb} /{ }^{238} \mathrm{U}$ & $\pm 2 \sigma$ \\
\hline $49 \mathrm{~B} / 27$ & 146 & 2951 & 6085 & 0.48 & 0.2416 & 0.0073 & 0.02164 & 0.00060 & 138.0 & 3.7 \\
\hline $49 \mathrm{~B} / 28$ & 152 & 4881 & 3177 & 1.54 & 0.3084 & 0.0099 & 0.03644 & 0.00100 & 230.7 & 6.2 \\
\hline $49 B / 29$ & 19 & 174 & 366 & 0.48 & 0.3545 & 0.0116 & 0.04924 & 0.00135 & 309.8 & 8.3 \\
\hline $49 \mathrm{~B} / 30$ & 25 & 142 & 519 & 0.27 & 0.3664 & 0.0127 & 0.04727 & 0.00130 & 297.7 & 8.0 \\
\hline $49 \mathrm{~B} / 31$ & 157 & 1600 & 4932 & 0.32 & 0.3757 & 0.0116 & 0.02759 & 0.00075 & 175.4 & 4.8 \\
\hline $49 \mathrm{~B} / 32$ & 54 & 219 & 1146 & 0.19 & 0.5134 & 0.0154 & 0.04418 & 0.00120 & 278.7 & 7.5 \\
\hline \multicolumn{11}{|c|}{ Tanargue granite 55 zircons } \\
\hline $55 / 1$ & 25 & 141 & 507 & 0.28 & 0.3577 & 0.0113 & 0.04926 & 0.00135 & 310.0 & 8.3 \\
\hline $55 / 2$ & 21 & 119 & 441 & 0.27 & 0.3480 & 0.0114 & 0.04856 & 0.00133 & 305.7 & 8.2 \\
\hline $55 / 3$ & 38 & 32 & 468 & 0.07 & 0.7115 & 0.0220 & 0.08741 & 0.00240 & 540.2 & 14.2 \\
\hline $55 / 4$ & 19 & 136 & 385 & 0.35 & 0.3670 & 0.0119 & 0.04902 & 0.00135 & 308.5 & 8.3 \\
\hline $55 / 5$ & 31 & 155 & 648 & 0.24 & 0.3712 & 0.0117 & 0.04851 & 0.00133 & 305.3 & 8.2 \\
\hline $55 / 6$ & 31 & 77 & 312 & 0.25 & 0.8480 & 0.0255 & 0.09991 & 0.00273 & 613.9 & 16.0 \\
\hline $55 / 7$ & 26 & 30 & 359 & 0.08 & 0.5920 & 0.0180 & 0.07603 & 0.00208 & 472.4 & 12.4 \\
\hline $55 / 8$ & 18 & 92 & 234 & 0.39 & 0.5819 & 0.0187 & 0.07524 & 0.00205 & 467.6 & 12.3 \\
\hline $55 / 9$ & 23 & 48 & 300 & 0.16 & 0.5922 & 0.0184 & 0.07777 & 0.00213 & 482.8 & 12.7 \\
\hline $55 / 10$ & 60 & 49 & 743 & 0.07 & 0.6952 & 0.0204 & 0.08617 & 0.00233 & 532.8 & 13.9 \\
\hline $55 / 11$ & 49 & 44 & 598 & 0.07 & 0.7101 & 0.0208 & 0.08827 & 0.00240 & 545.3 & 14.2 \\
\hline $55 / 12$ & 23 & 76 & 277 & 0.28 & 0.7625 & 0.0251 & 0.07980 & 0.00218 & 494.9 & 13.1 \\
\hline $55 / 13$ & 23 & 82 & 281 & 0.29 & 0.8112 & 0.0252 & 0.07840 & 0.00213 & 486.6 & 12.8 \\
\hline $55 / 14$ & 5 & 100 & 80 & 1.26 & 0.4010 & 0.0275 & 0.04991 & 0.00155 & 314.0 & 9.5 \\
\hline $55 / 15$ & 41 & 314 & 393 & 0.80 & 0.7646 & 0.0227 & 0.08898 & 0.00240 & 549.5 & 14.3 \\
\hline $55 / 16$ & 19 & 86 & 182 & 0.47 & 0.8186 & 0.0258 & 0.09780 & 0.00265 & 601.5 & 15.6 \\
\hline $55 / 17$ & 37 & 45 & 297 & 0.15 & 1.2343 & 0.0394 & 0.12951 & 0.00353 & 785.1 & 20.1 \\
\hline $55 / 18$ & 16 & 33 & 178 & 0.18 & 0.8016 & 0.0330 & 0.09160 & 0.00258 & 565.0 & 15.2 \\
\hline $55 / 19$ & 46 & 116 & 374 & 0.31 & 1.1537 & 0.0367 & 0.11680 & 0.00318 & 712.1 & 18.3 \\
\hline $55 / 20$ & 26 & 93 & 481 & 0.19 & 0.4303 & 0.0166 & 0.05467 & 0.00150 & 343.1 & 9.2 \\
\hline $55 / 21$ & 28 & 117 & 431 & 0.27 & 0.5322 & 0.0181 & 0.06434 & 0.00175 & 401.9 & 10.6 \\
\hline $55 / 22$ & 73 & 727 & 1434 & 0.51 & 0.3891 & 0.0143 & 0.04684 & 0.00128 & 295.1 & 7.9 \\
\hline $55 / 23$ & 22 & 276 & 184 & 1.50 & 0.6697 & 0.0223 & 0.08470 & 0.00230 & 524.1 & 13.7 \\
\hline $55 / 24$ & 6 & 76 & 118 & 0.64 & 0.3499 & 0.0146 & 0.04862 & 0.00135 & 306.0 & 8.3 \\
\hline $55 / 25$ & 5 & 55 & 96 & 0.57 & 0.3491 & 0.0211 & 0.04824 & 0.00143 & 303.7 & 8.8 \\
\hline $55 / 26$ & 19 & 387 & 305 & 1.27 & 0.3790 & 0.0130 & 0.04761 & 0.00130 & 299.8 & 8.0 \\
\hline $55 / 27$ & 9 & 150 & 149 & 1.01 & 0.3419 & 0.0137 & 0.04738 & 0.00130 & 298.4 & 8.0 \\
\hline $55 / 28$ & 5 & 58 & 76 & 0.77 & 0.4467 & 0.0270 & 0.05130 & 0.00155 & 322.5 & 9.5 \\
\hline \multicolumn{11}{|c|}{ Velay (Burzet) granite 20B zircons } \\
\hline $20 \mathrm{~B} / 1$ & 90 & 266 & 1617 & 0.16 & 0.6773 & 0.0207 & 0.05000 & 0.00135 & 314.5 & 8.4 \\
\hline $20 \mathrm{~B} / 2$ & 51 & 30 & 602 & 0.05 & 0.7676 & 0.0223 & 0.08868 & 0.00240 & 547.7 & 14.2 \\
\hline $20 \mathrm{~B} / 3$ & 30 & 92 & 532 & 0.17 & 0.7297 & 0.0223 & 0.04972 & 0.00135 & 312.8 & 8.3 \\
\hline $20 \mathrm{~B} / 4$ & 64 & 274 & 1261 & 0.22 & 0.3840 & 0.0120 & 0.05083 & 0.00138 & 319.6 & 8.4 \\
\hline $20 \mathrm{~B} / 5$ & 23 & 88 & 556 & 0.16 & 0.3239 & 0.0137 & 0.04429 & 0.00123 & 279.4 & 7.6 \\
\hline $20 \mathrm{~B} / 6$ & 73 & 142 & 1142 & 0.12 & 1.0941 & 0.0342 & 0.05136 & 0.00140 & 322.9 & 8.6 \\
\hline $20 \mathrm{~B} / 7$ & 64 & 265 & 1333 & 0.20 & 0.3764 & 0.0118 & 0.04903 & 0.00133 & 308.6 & 8.1 \\
\hline $20 \mathrm{~B} / 8$ & 22 & 28 & 287 & 0.10 & 0.9927 & 0.0344 & 0.07274 & 0.00200 & 452.7 & 12.0 \\
\hline $20 \mathrm{~B} / 9$ & 218 & 38 & 2893 & 0.01 & 0.6764 & 0.0197 & 0.08102 & 0.00215 & 502.2 & 12.8 \\
\hline $20 \mathrm{~B} / 10$ & 356 & 32 & 4480 & 0.01 & 0.7398 & 0.0210 & 0.08451 & 0.00223 & 523.0 & 13.3 \\
\hline $20 \mathrm{~B} / 11$ & 277 & 54 & 3496 & 0.02 & 0.8015 & 0.0230 & 0.08176 & 0.00215 & 506.6 & 12.9 \\
\hline $20 \mathrm{~B} / 12$ & 78 & 335 & 1548 & 0.22 & 0.3974 & 0.0116 & 0.05003 & 0.00133 & 314.7 & 8.1 \\
\hline $20 \mathrm{~B} / 13$ & 15 & 85 & 166 & 0.51 & 0.6929 & 0.0234 & 0.08612 & 0.00230 & 532.5 & 13.7 \\
\hline $20 B / 14$ & 48 & 188 & 1039 & 0.18 & 0.6853 & 0.0234 & 0.04138 & 0.00113 & 261.4 & 7.0 \\
\hline $20 \mathrm{~B} / 15$ & 57 & 172 & 1052 & 0.16 & 0.6695 & 0.0213 & 0.05039 & 0.00135 & 316.9 & 8.2 \\
\hline \multicolumn{11}{|c|}{ Peyron granite $15 D$ zircons } \\
\hline $15 \mathrm{D} / 1$ & 17 & 54 & 167 & 0.33 & 0.8689 & 0.0297 & 0.10176 & 0.00273 & 624.7 & 15.9 \\
\hline $15 \mathrm{D} / 2$ & 37 & 33 & 671 & 0.05 & 0.4673 & 0.0145 & 0.05791 & 0.00153 & 362.9 & 9.3 \\
\hline $15 \mathrm{D} / 3$ & 43 & 153 & 825 & 0.19 & 0.4068 & 0.0154 & 0.05101 & 0.00138 & 320.7 & 8.5 \\
\hline $15 \mathrm{D} / 4$ & 110 & 86 & 1200 & 0.07 & 0.8201 & 0.0226 & 0.09773 & 0.00258 & 601.1 & 15.1 \\
\hline $15 \mathrm{D} / 5$ & 72 & 357 & 732 & 0.49 & 0.7707 & 0.0218 & 0.09208 & 0.00243 & 567.8 & 14.3 \\
\hline $15 \mathrm{D} / 6$ & 15 & 109 & 69 & 1.58 & 1.6572 & 0.0596 & 0.16402 & 0.00445 & 979.1 & 24.7 \\
\hline $15 \mathrm{D} / 7$ & 60 & 168 & 922 & 0.18 & 0.5363 & 0.0162 & 0.06548 & 0.00173 & 408.9 & 10.5 \\
\hline $15 \mathrm{D} / 8$ & 114 & 1074 & 928 & 1.16 & 0.8659 & 0.0240 & 0.10214 & 0.00270 & 626.9 & 15.7 \\
\hline $15 \mathrm{D} / 9$ & 95 & 65 & 352 & 0.18 & 4.6483 & 0.1294 & 0.26166 & 0.00693 & 1498.3 & 35.4 \\
\hline
\end{tabular}


Tab. 2 Continued

\begin{tabular}{|c|c|c|c|c|c|c|c|c|c|c|}
\hline \multirow[b]{2}{*}{ Spot } & \multicolumn{4}{|c|}{ Concentrations } & \multicolumn{4}{|c|}{ Isotopic ratios } & \multicolumn{2}{|c|}{ Age (Ma) } \\
\hline & Pb ppm ${ }^{1}$ & Th ppm $^{1}$ & $\mathrm{U}_{\mathrm{ppm}}{ }^{1}$ & Th/U & ${ }^{207} \mathbf{P b} /{ }^{235} \mathbf{U}^{2}$ & $\pm 2 \sigma$ & ${ }^{206} \mathrm{~Pb} /{ }^{238} \mathrm{U}^{2}$ & $\pm 2 \sigma$ & ${ }^{206} \mathbf{P b} / /{ }^{238} \mathbf{U}$ & $\pm 2 \sigma$ \\
\hline $15 \mathrm{D} / 10$ & 15 & 57 & 153 & 0.37 & 0.7822 & 0.0285 & 0.09343 & 0.00253 & 575.8 & 14.9 \\
\hline $15 \mathrm{D} / 11$ & 35 & 68 & 341 & 0.20 & 0.9150 & 0.0275 & 0.10447 & 0.00278 & 640.5 & 16.2 \\
\hline $15 \mathrm{D} / 12$ & 211 & 145 & 2871 & 0.05 & 0.6689 & 0.0184 & 0.07785 & 0.00205 & 483.3 & 12.3 \\
\hline $15 \mathrm{D} / 13$ & 82 & 620 & 778 & 0.80 & 0.8375 & 0.0237 & 0.09519 & 0.00253 & 586.1 & 14.8 \\
\hline $15 \mathrm{D} / 14$ & 69 & 856 & 295 & 2.90 & 1.5032 & 0.0436 & 0.14990 & 0.00398 & 900.4 & 22.3 \\
\hline $15 \mathrm{D} / 15$ & 184 & 77 & 2149 & 0.04 & 0.8424 & 0.0238 & 0.09030 & 0.00240 & 557.3 & 14.2 \\
\hline $15 \mathrm{D} / 16$ & 39 & 181 & 353 & 0.51 & 0.9134 & 0.0269 & 0.10523 & 0.00280 & 645.0 & 16.3 \\
\hline $15 \mathrm{D} / 17$ & 70 & 494 & 673 & 0.73 & 0.8271 & 0.0236 & 0.09514 & 0.00253 & 585.8 & 14.9 \\
\hline $15 \mathrm{D} / 18$ & 12 & 28 & 27 & 1.02 & 6.0881 & 0.1891 & 0.35389 & 0.00960 & 1953.2 & 45.7 \\
\hline $15 \mathrm{D} / 19$ & 43 & 106 & 287 & 0.37 & 1.4502 & 0.0424 & 0.14815 & 0.00395 & 890.6 & 22.2 \\
\hline $15 \mathrm{D} / 20$ & 31 & 328 & 255 & 1.29 & 0.8612 & 0.0264 & 0.10090 & 0.00270 & 619.7 & 15.8 \\
\hline $15 \mathrm{D} / 21$ & 35 & 32 & 740 & 0.04 & 0.3928 & 0.0127 & 0.04993 & 0.00135 & 314.1 & 8.3 \\
\hline $15 \mathrm{D} / 22$ & 20 & 90 & 174 & 0.52 & 1.3026 & 0.0408 & 0.09692 & 0.00263 & 596.3 & 15.4 \\
\hline $15 \mathrm{D} / 23$ & 35 & 130 & 182 & 0.72 & 1.7461 & 0.0520 & 0.17303 & 0.00463 & 1028.8 & 25.5 \\
\hline $15 \mathrm{D} / 24$ & 30 & 99 & 314 & 0.32 & 0.8046 & 0.0254 & 0.08800 & 0.00238 & 543.7 & 14.1 \\
\hline $15 \mathrm{D} / 25$ & 23 & 97 & 193 & 0.50 & 0.9470 & 0.0296 & 0.11000 & 0.00295 & 672.8 & 17.2 \\
\hline $15 \mathrm{D} / 26$ & 27 & 2 & 638 & 0.004 & 0.3425 & 0.0108 & 0.04674 & 0.00125 & 294.5 & 7.8 \\
\hline $15 \mathrm{D} / 27$ & 19 & 129 & 141 & 0.92 & 1.1068 & 0.0367 & 0.11442 & 0.00310 & 698.3 & 18.0 \\
\hline $15 \mathrm{D} / 28$ & 65 & 255 & 647 & 0.39 & 0.7999 & 0.0242 & 0.09583 & 0.00258 & 590.0 & 15.2 \\
\hline $15 \mathrm{D} / 29$ & 98 & 222 & 1386 & 0.16 & 0.6243 & 0.0186 & 0.07218 & 0.00195 & 449.3 & 11.7 \\
\hline $15 \mathrm{D} / 30$ & 53 & 147 & 557 & 0.26 & 0.8797 & 0.0268 & 0.09352 & 0.00253 & 576.3 & 14.9 \\
\hline $15 \mathrm{D} / 31$ & 156 & 373 & 286 & 1.30 & 10.1131 & 0.2967 & 0.39389 & 0.01063 & 2140.8 & 49.2 \\
\hline $15 \mathrm{D} / 32$ & 170 & 1609 & 1176 & 1.37 & 0.9649 & 0.0293 & 0.10911 & 0.00295 & 667.6 & 17.1 \\
\hline $15 \mathrm{D} / 33$ & 169 & 718 & 1684 & 0.43 & 0.8371 & 0.0248 & 0.09611 & 0.00260 & 591.6 & 15.2 \\
\hline $15 \mathrm{D} / 34$ & 126 & 272 & 941 & 0.29 & 1.2380 & 0.0366 & 0.13297 & 0.00358 & 804.8 & 20.4 \\
\hline $15 \mathrm{D} / 35$ & 64 & 367 & 602 & 0.61 & 0.7997 & 0.0243 & 0.09645 & 0.00260 & 593.6 & 15.3 \\
\hline $15 \mathrm{D} / 36$ & 58 & 220 & 564 & 0.39 & 0.8199 & 0.0250 & 0.09804 & 0.00265 & 602.9 & 15.6 \\
\hline \multicolumn{11}{|c|}{ Velay (Burzet) granite $20 B$ monazites } \\
\hline Mz20B/1 & 1660 & 61727 & 19090 & 3.2 & 0.3453 & 0.0109 & 0.04937 & 0.00153 & 310.6 & 9.4 \\
\hline $\mathrm{Mz} 20 \mathrm{~B} / 2$ & 1104 & 39585 & 13137 & 3.0 & 0.3442 & 0.0109 & 0.04931 & 0.00153 & 310.3 & 9.4 \\
\hline $\mathrm{Mz} 20 \mathrm{~B} / 3$ & 1432 & 48735 & 18117 & 2.7 & 0.3413 & 0.0107 & 0.04919 & 0.00153 & 309.6 & 9.4 \\
\hline $\mathrm{Mz} 20 \mathrm{~B} / 4$ & 1619 & 55927 & 19855 & 2.8 & 0.3477 & 0.0109 & 0.04989 & 0.00155 & 313.8 & 9.5 \\
\hline $\mathrm{Mz} 20 \mathrm{~B} / 5$ & 1233 & 53989 & 11615 & 4.6 & 0.3503 & 0.0113 & 0.04860 & 0.00150 & 305.9 & 9.3 \\
\hline $\mathrm{Mz} 20 \mathrm{~B} / 6$ & 1891 & 56498 & 27234 & 2.1 & 0.3561 & 0.0112 & 0.04905 & 0.00153 & 308.7 & 9.3 \\
\hline $\mathrm{Mz} 20 \mathrm{~B} / 7$ & 976 & 55273 & 4289 & 12.9 & 0.3505 & 0.0127 & 0.04956 & 0.00155 & 311.8 & 9.5 \\
\hline $\mathrm{Mz} 20 \mathrm{~B} / 8$ & 1647 & 59426 & 19794 & 3.0 & 0.3483 & 0.0110 & 0.04922 & 0.00153 & 309.7 & 9.4 \\
\hline $\mathrm{Mz} 20 \mathrm{~B} / 9$ & 1421 & 49279 & 17593 & 2.8 & 0.3453 & 0.0111 & 0.04928 & 0.00153 & 310.1 & 9.4 \\
\hline Mz20B/10 & 1255 & 47510 & 14559 & 3.3 & 0.3505 & 0.0114 & 0.04867 & 0.00150 & 306.4 & 9.3 \\
\hline Mz20B/11 & 1419 & 56117 & 14761 & 3.8 & 0.3553 & 0.0126 & 0.04814 & 0.00150 & 303.1 & 9.2 \\
\hline Mz20B/12 & 988 & 55089 & 4302 & 12.8 & 0.3486 & 0.0118 & 0.04958 & 0.00153 & 311.9 & 9.4 \\
\hline Mz20B/13 & 1292 & 53709 & 13084 & 4.1 & 0.3439 & 0.0112 & 0.04915 & 0.00153 & 309.3 & 9.3 \\
\hline Mz20B/14 & 1128 & 60466 & 6646 & 9.1 & 0.3583 & 0.0119 & 0.04919 & 0.00153 & 309.5 & 9.4 \\
\hline $\mathrm{Mz20B} / 15$ & 1269 & 66401 & 8085 & 8.2 & 0.3500 & 0.0124 & 0.04951 & 0.00155 & 311.5 & 9.5 \\
\hline Mz20B/16 & 1532 & 75071 & 11043 & 6.8 & 0.3543 & 0.0124 & 0.04980 & 0.00155 & 313.3 & 9.5 \\
\hline Mz20B/17 & 1602 & 50124 & 22211 & 2.3 & 0.3391 & 0.0111 & 0.04947 & 0.00153 & 311.3 & 9.4 \\
\hline Mz20B/18 & 990 & 64168 & 2923 & 22.0 & 0.3587 & 0.0143 & 0.04850 & 0.00153 & 305.3 & 9.4 \\
\hline Mz20B/19 & 1157 & 57582 & 7627 & 7.5 & 0.3416 & 0.0124 & 0.04898 & 0.00153 & 308.3 & 9.4 \\
\hline $\mathrm{Mz} 20 \mathrm{~B} / 20$ & 1676 & 72177 & 16283 & 4.4 & 0.3515 & 0.0118 & 0.04896 & 0.00153 & 308.2 & 9.3 \\
\hline Mz20B/21 & 1268 & 55663 & 11535 & 4.8 & 0.3423 & 0.0125 & 0.04895 & 0.00153 & 308.1 & 9.4 \\
\hline $\mathrm{Mz} 20 \mathrm{~B} / 22$ & 1656 & 78194 & 14240 & 5.5 & 0.3459 & 0.0117 & 0.04938 & 0.00153 & 310.7 & 9.4 \\
\hline $\mathrm{Mz} 20 \mathrm{~B} / 23$ & 2006 & 60256 & 30235 & 2.0 & 0.3403 & 0.0118 & 0.04816 & 0.00150 & 303.2 & 9.2 \\
\hline \multicolumn{11}{|c|}{ Peyron granite 15D monazites } \\
\hline $\mathrm{Mz} 15 \mathrm{D} / 1$ & 1188 & 35350 & 17609 & 2.0 & 0.3414 & 0.0117 & 0.04914 & 0.00153 & 309.2 & 9.3 \\
\hline $\mathrm{Mz} 15 \mathrm{D} / 2$ & 847 & 30512 & 10643 & 2.9 & 0.3408 & 0.0119 & 0.04899 & 0.00153 & 308.3 & 9.3 \\
\hline $\mathrm{Mz} 15 \mathrm{D} / 3$ & 1008 & 29916 & 14855 & 2.0 & 0.3409 & 0.0121 & 0.04894 & 0.00153 & 308.0 & 9.3 \\
\hline $\mathrm{Mz} 15 \mathrm{D} / 4$ & 914 & 29722 & 12769 & 2.3 & 0.3458 & 0.0127 & 0.04908 & 0.00153 & 308.9 & 9.4 \\
\hline $\mathrm{Mz} 15 \mathrm{D} / 5$ & 983 & 33743 & 12740 & 2.6 & 0.3447 & 0.0130 & 0.04895 & 0.00153 & 308.1 & 9.4 \\
\hline
\end{tabular}

${ }^{1}$ : concentration uncertainty c. $20 \%$

2: data not corrected for common $\mathrm{Pb}$

Decay constants of Jaffrey et al. (1971) used 

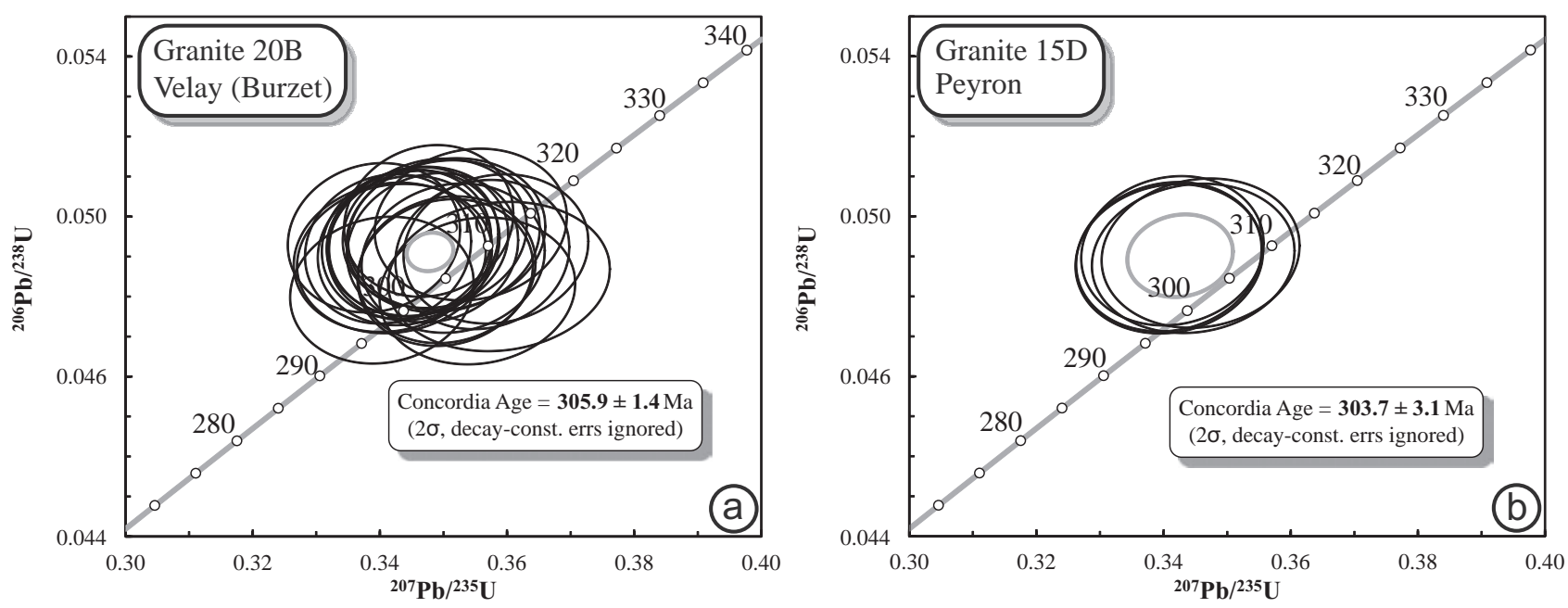

Fig. 5 Concordia diagrams for monazites in the Velay and Peyron granites.

sult of their very high $\mathrm{U}$ content, these metamict zircons may be systematically discordant and consequently the $294 \mathrm{Ma}$ age would only be a minimum estimate. On the other hand, Pont-de-Bayzan is located close to the major La Souche Fault (Fig. 1) that also controlled the formation of the Stephanian Jaujac Basin (Weisbrod 1970). It can therefore be proposed that (a) this fault remained active until the Permian, draining the last mantle-derived magmas into the upper crust (see Scarrow et al. 2011). Indeed, the emplacement of at least some of the Pont-deBayzan bodies was clearly fault controlled (Fig. 2 and Appendix). Perhaps more likely, (b) the fault activity was associated with fluid circulation and perturbation of the isotopic system, an interpretation consistent with the scattering of the $\mathrm{U}-\mathrm{Pb}$ data for this sample.

\subsection{Host control on mafic magmas emplacement}

In previous studies (Aït Malek 1997), the different shapes of vaugnerite bodies were considered to reflect successive magma batches and were used to discriminate between early, $\mathrm{D}_{3}$-related, and late, $\mathrm{D}_{4}$-related, intrusions. However, such an interpretation is not consistent with the undistinguishable within error ages obtained, regardless of the nature of the country rocks and degree of deformation of the vaugnerites. The various intrusions forms may be explained primarily by the contrasting rheological properties of the host. In partially molten systems, the melt fraction has a considerable impact on the rheology of the rock (e.g. Arzi 1978; Vigneresse et al. 2008; Vanderhaeghe 2009). Low-melt fraction systems behave as solids, whereas melt-rich rocks may attain a liquid-like rheology. In the Southern Velay, the vaugneritic intrusions are hosted by both migmatitic orthogneiss and paragneiss, which show evidence for
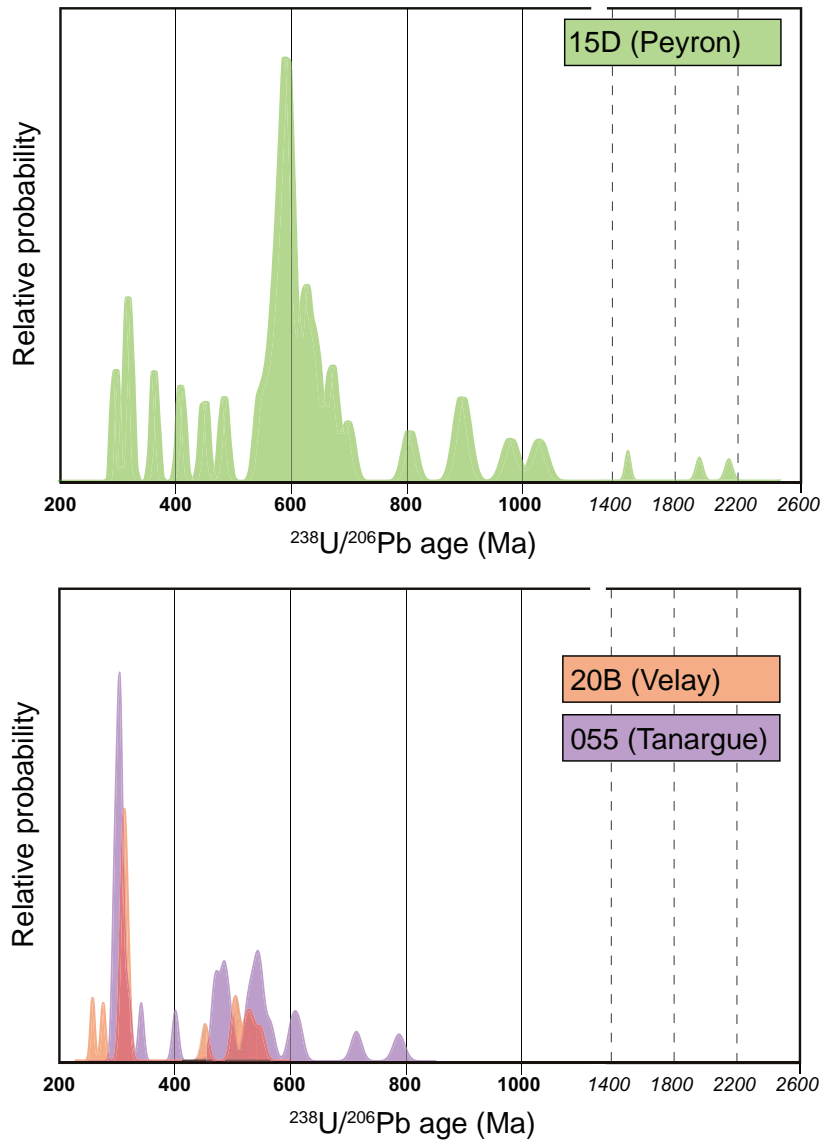

Fig. 6 Distribution of concordant and sub-concordant ages in the three peraluminous granites analysed: 15D (Peyron), top, 20B (Velay) and 55 (Tanargue), bottom. Note the scale break at 1000 Ma.

variable degree of anatexis, i.e. contrasting amounts of melt present. Vaugnerites hosted in low-melt fraction paragneisses or orthogneisses form sills or dyke swarms creeping in the migmatite melt network and mimicking the host foliation. In contrast, vaugnerites that intruded 
into diatexitic paragneisses form round, apparently undeformed masses.

\subsection{The source of Southern Velay granites}

Although all the granites in our study area are nearly coeval, contrasting zircon inheritance patterns reveal that they were derived from distinct sources. The Peyron granite (a late phase of the Velay Complex) appears to have been generated from an old Cadomian crust, with a dominant c. 600 Ma peak (Fig. 6), as well as evidence for much older (early Proterozoic) components. Similar, early Proterozoic ages are known throughout the Massif Central in metasediments (see review in Melleton et al. 2010). Inherited ages of the Tanargue granite cluster at 540 and $470 \mathrm{Ma}$, corresponding to Cambrian and Ordovician magmatic events well known in the French Massif Central (e.g. R'Kha Chaham et al. 1990; Roger et al. 2004). The Velay granite proper shows a mostly Cambrian inheritance. By contrast, the Largentière granite shows no inheritance, suggesting that it originated from a juvenile protolith. Vaugnerites are likely to represent such a source since geochemical similarities suggest fractionation or remelting of newly emplaced $\mathrm{Mg}-\mathrm{K}$ mafic rocks. Alternately, the (apparent) lack of inheritance could be a feature of the easy dissolution of high-U, likely metamict, zircons from the source; thereby providing a local U source allowing crystallization of Largentière granite's U-rich zircons (Schmidt et al. 2006). Thus, many parts of the Variscan crust experienced partial melting at the same time (305 Ma) leading to the production of granitic bodies from contrasting sources.

\subsection{Long-lived crustal melting and catastrophic granite production}

A compilation of $\mathrm{U}-\mathrm{Pb}$ zircon and monazite magmatic ages available in the area (Fig. 7) shows that the great majority of granite plutons (excluding the early Rocles granite) were emplaced at around the same time. Both the late-granites from the Tanargue suite and the supposed "pre-Velay" Mont Lozère-Borne-Largentière granite intruded within the same short period as the main Velay granite, i.e. at c. $305 \mathrm{Ma}$.

However, the zircon age pattern of the Velay granite reveals the presence of Early Carboniferous zircons ( $\sim 320 \mathrm{Ma})$, in addition to the older (source-related?) zircons (Fig. 6). This demonstrates that the main regional granitic event, the " $\mathrm{M}_{4}$ " HT crustal anatexis (Barbey et al. 1999; Ledru et al. 2001) followed a protracted period

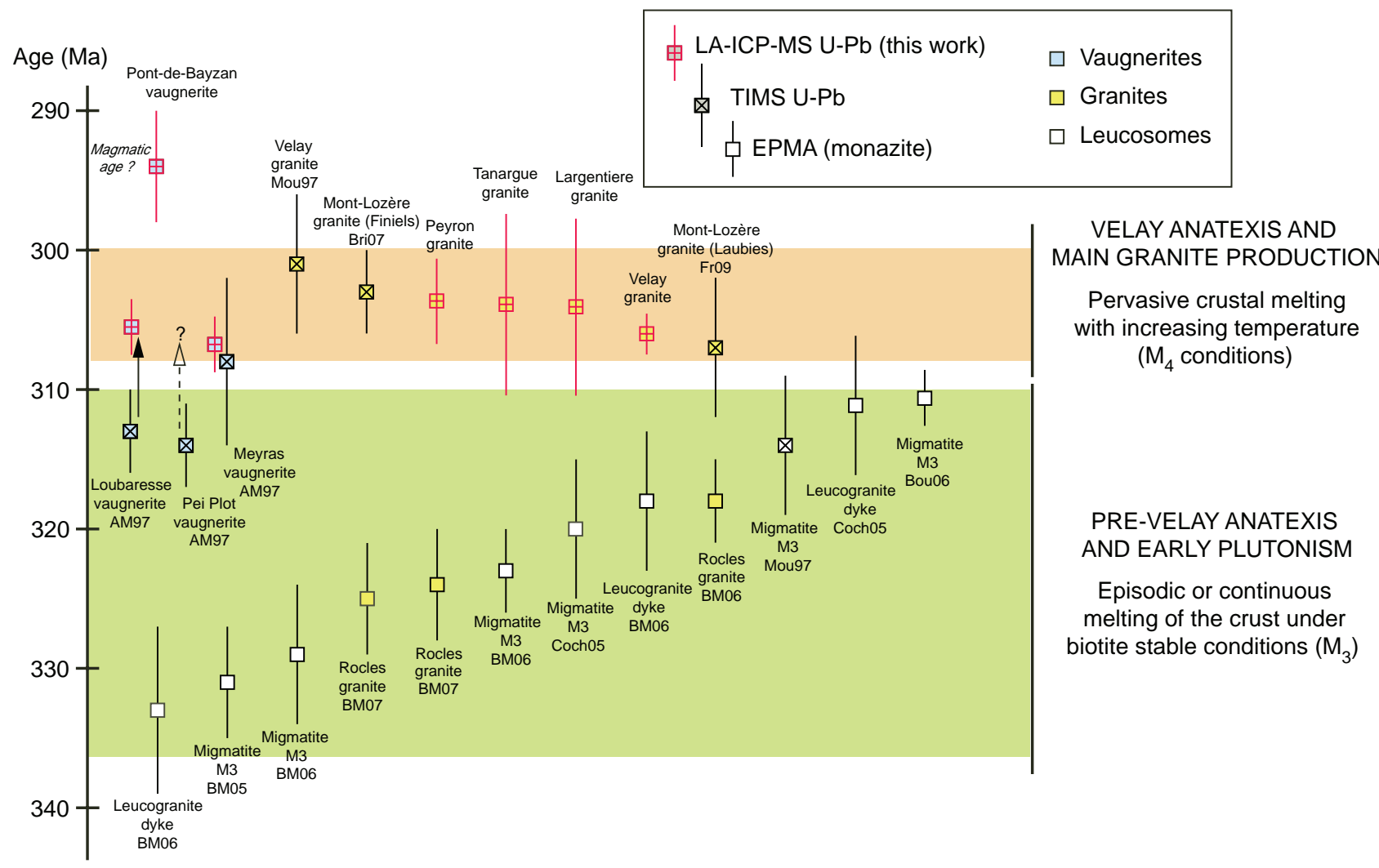

Fig. 7 Synthesis of U-Pb zircon (squares with symbols) and monazite (empty squares) ages with errors. Data sources: AM97: Ait Malek (1997); BM05: Be Mezeme et al. (2005); BM06: Be Mezeme et al. (2006); BM07: Be Mezeme et al. (2007); Bou06: Bouilhol et al. (2006); Bri07: Brichau et al. (2007); Coch05: Cocherie et al. (2005); Fr09: François (2009); Mou97: Mougeot et al. (1997). Red symbols: this study. 
of pre-Velay $\left(\mathrm{M}_{3}\right)$ anatexis spanning between 335 and $310 \mathrm{Ma}$ (Fig. 7). The $\mathrm{M}_{3}$ event is recorded by the early "Velay" zircons, the Rocles granite (Be Mezeme et al. 2007) and the "low-temperature" (biotite stable; Montel et al. 1992) anatexis of the regional paragneisses (Mougeot et al. 1997; Be-Mezeme et al. 2005; Cocherie et al. 2005; Be Mezeme et al. 2006). Available data (Fig. 7) suggest that the $\mathrm{M}_{3}$ melting was rather long-lived (>20 Ma), but did not result in the formation of large granitic bodies; melt remained confined to migmatites and was rarely extracted and transferred into true plutons. A similar pattern has been described in other segments of the Variscan belt, such as Central Spain (Montero et al. 2004) or Calabria (Schenk 1990; Graessner et al. 2000), suggesting that this process occurred throughout the whole Variscan belt.

The $M_{3}$ and $M_{4}$ events, therefore, were very distinct. During $M_{3}$ anatexis, melt mostly remained trapped in its source. In contrast, during $\mathrm{M}_{4}$, melt was extracted and collected in plutons. This difference most likely relates to temperature, which was some $50-100^{\circ} \mathrm{C}$ higher during $\mathrm{M}_{4}$. A higher temperature has two important consequences. Firstly, it results in a higher degree of anatexis that may be enough to bring the partially molten crust above the "Rheologically Critical Melt Percentage", (RCMP; Arzi 1978; Rosenberg 2001; Vigneresse and Burg 2004) above which the partially molten rocks behave as liquids, rather than solids. Secondly, the onset of biotite breakdown causes the disruption of the solid framework of melanosomes that holds the liquid in poorly connected leucosomes (Barraud et al. 2004). When these biotite-dominated layers collapse, the connectivity of the melt network suddenly increases, allowing melt extraction and formation of true plutons. Therefore, even the moderate heating at the $\mathrm{M}_{3}-\mathrm{M}_{4}$ transition may have been sufficient to cause a major shift in the overall mechanical behaviour of the crust.

\subsection{Vaugnerites and the $M_{3}-M_{4}$ transition}

The $\mathrm{M}_{3}-\mathrm{M}_{4}$ transition corresponded to moderate heating that resulted in an important rheological and tectonic change. The vaugnerites emplaced at this very moment and it is therefore clear that they are somehow related to this catastrophic process. Yet, their exact role remains unclear. Vaugnerites could be the actual cause: a sudden influx of mafic magmas in the already molten crust could have supplied enough heat to trigger the $\mathrm{M}_{3}-\mathrm{M}_{4}$ transition. Estimating the total volume of vaugnerites is difficult, because they crop out as rather common, but small, bodies. Therefore, it is hard to decide whether they are a volumetrically minor, or significant, component; and how much heat they could have transferred to the crust. Alternately, vaugnerites could just be the result of the same process that independently caused the heating of the crust: slab breakoff (Davies and von Blanckenburg 1995; van de Zedde and Wortel 2001; Atherton and Ghani 2002; Janoušek and Holub 2007), delamination of a lithospheric mantle root (Houseman et al. 1981; Houseman and Molnar 2001; Molnar and Houseman 2004) or orogenic collapse (England and Thompson 1984; Malavieille et al. 1990; Gardien et al. 1997; Rey et al. 2001; Vanderhaeghe and Teyssier 2001). All these processes would result in sudden heating of the crust, as well as concomitant generation of mafic melts (Arnold et al. 2001; Clark et al. 2011; Lexa et al. 2011).

\subsection{The hot late Variscan crust}

It is worth pointing out that $\mathrm{M}_{4}$ corresponded to fairly extreme geothermal gradients: $800^{\circ} \mathrm{C}$ for $2-5 \mathrm{kbar}$, i.e. $50-130^{\circ} \mathrm{C} / \mathrm{km}$. It is, of course, totally unrealistic to extrapolate these gradients through the whole crust (as this would imply a Moho temperature greater than $1500^{\circ} \mathrm{C}$ ). Therefore, the geotherm in the lower portions of the crust during $\mathrm{M}_{4}$ times must have been much steeper, with a lower dT/dP. A similar "Z-shaped" geotherm has been advocated for "ultra-hot" orogens, such as those found in the Proterozoic or Archaean (Depine et al. 2008, Chardon et al. 2009). During at least a short period of its history, the Variscan belt was, in many respects, similar to such ultra-hot orogenic domains.

\section{Conclusions}

This work presents some of the first in-situ (LA-ICP-MS) ages for the southern French Massif Central granites and vaugnerites. Most of them were emplaced during a short time period at c. $305 \mathrm{Ma}$. This massive event of melting and catastrophic collapse of the orogenic crust followed a long-lived period (c. 20-30 Ma), during which the crust was partially molten but melts remained trapped and were not extracted to form granitic plutons. Crustal melting reached a climax at $305 \mathrm{Ma}$ linked to a temperature increase that provoked biotite breakdown, thus leading to emplacement of the main cordierite-bearing Velay granite. This $\mathrm{M}_{4}$ event of granite production was synchronous with intrusion of $\mathrm{Mg}-\mathrm{K}$ mafic mantle-derived magmas in the middle crust. The catastrophic destabilization of the partially molten Variscan crust led to massive melt extraction from various crustal sources (older ortho- and paragneisses, newly emplaced vaugnerites), and so to the formation of numerous granitic plutons. It remains unclear whether the coeval $\mathrm{Mg}-\mathrm{K}$ magmatism acted as a trigger for the eventual orogenic collapse or was just an expression of the HT regime. However, it is a key marker of the end of orogenic periods. 
Acknowledgements. Pierre Bouilhol, Philippe-Hervé Leloup and Oscar Laurent are thanked for comments on earlier versions of this work and stimulating discussions. JHS was financially supported by the Spanish grant CGL2008-02864 and the Andalusian grant RNM1595. Reviews from Jean-Louis Vigneresse and František Holub helped to improve the quality of the manuscript. Editorial handling by Miroslav Štemprok and Vojtěch Janoušek was greatly appreciated.

Electronic supplementary material. The sample descriptions and locations are available online at the Journal web site (http://dx.doi.org/10.3190/jgeosci.155).

\section{References}

Aït Malek H (1997) Petrology, geochemistry and U/Pb geochronology of acid-basic associations: examples from SE Velay (French Massif Central) and western antiAtlas (Morocco). Unpublished PhD thesis, University of Nancy, pp 1-297 (in French)

AlexandRe P (2007) U-Pb zircon SIMS ages from the French Massif Central and implication for the preVariscan tectonic evolution in Western Europe. C R Geosci 339: 613-621

Arnold J, Jacoby W, Schmeling H, Schott B (2001) Continental collision and the dynamic and thermal evolution of the Variscan orogenic crustal root - numerical models. J Geodyn 31: 273-291

ArZI AA (1978) Critical phenomena in the rheology of partially melted rocks. Tectonophysics 44: 173-184

Atherton MP, GHANi AA (2002) Slab breakoff; a model for Caledonian, Late Granite syn-collisional magmatism in the orthotectonic (metamorphic) zone of Scotland and Donegal, Ireland. Lithos 62: 65-85

Barbey P, Marignac C, Montel JM, Macaudiere J, GasQUET D, JABBORI J (1999) Cordierite growth textures and the conditions of genesis and emplacement of crustal granitic magmas: the Velay granite Complex (Massif Central, France). J Petrol 40: 1425-1441

Barraud J, Gardien V, Allemand P, Grandjean P (2004) Analogue models of melt-flow networks in folding migmatites. J Struct Geol 26: 307-324

Be Mezeme E, Faure M, Cocherie A, Chen Y (2005) In situ chemical dating of tectonothermal events in the French Variscan Belt. Terra Nova 17: 420-426

Be Mezeme E, Cocherie A, Faure M, Legendre O, Rossi P (2006) Electron microprobe monazite geochronology of magmatic events: example from Variscan migmatites and granitoids, Massif Central, France. Lithos 87: 276-288

Be Mezeme E, Faure M, Chen Y, Cocherie A, Talbot JY (2007) Structural, AMS and geochronological study of a laccolith emplaced during Late Variscan orogenic exten- sion: the Rocles Pluton (SE French Massif Central). Int J Earth Sci 96: 215-228

Bea F, Montero P, Ortega M (2006) A LA-ICP-MS evaluation of $\mathrm{Zr}$ reservoirs in common crustal rocks: implications for $\mathrm{Zr}$ and $\mathrm{Hf}$ geochemistry, and zircon-forming processes. Canad Mineral 44: 693-714

Berger J, Féménias O, Ohnenstetter D, Bruguier O, Plissart G, Mercier JCC, Demaiffe D (2010) New occurrence of UHP eclogites in Limousin (French Massif Central): age, tectonic setting and fluid-rock interactions. Lithos 118: 365-382

Bonin B (2004) Do coeval mafic and felsic magmas in post-collisional to within-plate regimes necessarily imply two contrasting, mantle and crustal, sources? A review. Lithos 78: 1-24

Bouilhol P, Leyreloup AF, Delor C, Vauchez A, Monié P (2006) Relationships between lower and upper crust tectonic during doming: the mylonitic southern edge of the Velay metamorphic core complex (Cévennes - French Massif Central). Geodin Acta 19: 137-153

Bowes D, KošLer J (1993) Geochemical comparison of the subvolcanic appinite suite of the British Caledonides and the durbachite suite of the Central European Hercynides: evidence for associated shoshonitic and granitic magmatism. Mineral Petrol 48: 47-63

Brichau S, Respaut JP, Monié P (2008) New age constraints on emplacement of the Cévenol granitoids, South French Massif Central. Int J Earth Sci 97: 725-738

CAen-Vachette M, Couturié J, Didier J (1982) Radiometric ages of anatectic and late-migmatitic Velay granites (French Massif Central). C R Acad Sci Paris 294: 135-138 (in French)

CARON C (1994) $\mathrm{Pb}-\mathrm{Zn}$ mineralizations in the lower Paleozoic of southern Europe. Isotopic $\mathrm{Pb}$ study of Iglesiente (SW Sardaigne) and Cévennes mineral deposits, and evolution of the country rocks using $\mathrm{U}-\mathrm{Pb}, \mathrm{Ar}-\mathrm{Ar}$ and $\mathrm{K}-\mathrm{Ar}$ geochronology. Unpublished $\mathrm{PhD}$ thesis, University of Montpellier, pp 1-288 (in French)

Castro A, Corretgé LG, De la Rosa J, Fernández C, López S, García-Moreno O, Chacón H (2003) The AppiniteMigmatite Complex of Sanabria, NW Iberian Massif, Spain. J Petrol 44: 1309-1344

Chardon D, Gapais D, Cagnard F (2009) Flow of ultrahot orogens: a view from the Precambrian, clues for the Phanerozoic. Tectonophysics 477: 105-118

Clark C, Fitzsimons ICW, Healy D, Harley SL (2011) When the continental crust melts: how does the continental crust get really hot? Elements 7: 235-240

Cocherie A, Mezeme EB, Legendre O, Fanning CM, Faure M, Rossi P (2005) Electron-microprobe dating as a tool for determining the closure of Th-U-Pb systems in migmatitic monazites. Amer Miner 90: 607-618

Costa S, Rey P (1995) Lower crustal rejuvenation and growth during post-thickening collapse: insights from 
a crustal cross section through a Variscan metamorphic core complex. Geology 23: 905

Davies JH, von BlanckenbuRg F (1995) Slab breakoff: a model of lithosphere detachment and its test in the magmatism and deformation of collisional orogens. Earth Planet Sci Lett 129: 85-102

Depine GV, Andronicos CL, Phipps-Morgan J (2008) Nearisothermal conditions in the middle and lower crust induced by melt migration. Nature 452: 80-83

Didier A, Bosse V, Boulvais P, Bouloton J, Paquette JL, Montel JM, Devidal JL (2013) Disturbance versus preservation of $\mathrm{U}-\mathrm{Th}-\mathrm{Pb}$ ages in monazite during fluid-rock interaction: textural, chemical and isotopic in situ study in microgranites (Velay Dome, France). Contrib Mineral Petrol 165: 1051-1072

Didier J, Azelarab ELM, Fernandez A (1987) Interactions between a diorite magma and a palingenetic granitic magma at the Peyron, near Burzet (Ardèche, French Massif Central). C R Acad Sci Paris 304: 1227-1232 (in French)

Downes H, Shaw A, Williamson BJ, Thirlwall MF (1997) $\mathrm{Sr}, \mathrm{Nd}$ and $\mathrm{Pb}$ isotopic evidence for the lower crustal origin of Hercynian granodiorites and monzogranites, Massif Central, France. Chem Geol 140: 289-289

Ducrot J, Lancelot JR, Marchand J (1983) U-Pb dating on zircons on La-Borie eclogite (Haut-Allier, France) and consequences on the Ante-Hercynian evolution of Occidental Europe. Earth Planet Sci Lett 62: 385-394

EdeL JB (2001) The rotations of the Variscides during the Carboniferous collision: paleomagnetic constraints from the Vosges and the Massif Central (France). Tectonophysics 332: 69-92

England PC, Thompson AB (1984) Pressure-temperaturetime paths of regional metamorphism, part I: heat transfer during the evolution of regions of thickened continental crust. J Petrol 25: 894-928

Faure M, Lardeaux JM, Ledru P (2009) A review of the pre-Permian geology of the Variscan French Massif Central. C R Geosci 341: 202-213

Fowler MB (1988) Ach'uaine hybrid appinite pipes - evidence for mantle-derived shoshonitic parent magmas in Caledonian granite genesis. Geology 16: 1026-1030

Fowler M, Rollinson H (2012) Phanerozoic sanukitoids from Caledonian Scotland: implications for Archean subduction. Geology 40: 1079-1082

Fowler M, Kocks H, Darbyshire D, Greenwood P (2008) Petrogenesis of high $\mathrm{Ba}-\mathrm{Sr}$ plutons from the Northern Highlands Terrane of the British Caledonian Province. Lithos 105: 129-148

FrançoIs T (2009) Geochemical and geochronological constraints on the origin and emplacement of Mont-Lozère granites. Unpublished MSci., University of Montpellier, pp 1-39 (in French)

GAGNY C (1979) Vaugnerites and durbachites are cumulates derived from a granitic magma (example of the Crêtes magma, Vosges). C R Acad Sci Paris 287: 1361-1364 (in French)

Gardien V, Lardeaux JM, Ledru P, Allemand P, Guillot $S$ (1997) Metamorphism during late orogenic extension: insights from the French Variscan belt. Bull Soc Geol Fr 168: 271-286

Gasquet D, Bertrand JM, Paquette JL, Lehmann J, Ratzov G, Guedes RDA, Tiepolo M, Boullier AM, Scaillet S, Nomade S (2010) Miocene to Messinian deformation and hydrothermal activity in a pre-Alpine basement massif of the French western Alps: new U-Th- $\mathrm{Pb}$ and argon ages from the Lauzière Massif. Bull Soc Geol Fr 181: $227-241$

Gerdes A, Wörner G, Finger F (2000) Hybrids, magma mixing and enriched mantle melts in post-collisional Variscan granitoids: the Rastenberg Pluton, Austria. In: Franke W, HaAk V, Oncken O, Tanner D (eds) Orogenic Processes: Quantification and Modelling in the Variscan Belt. Geological Society London Special Publications 179: pp 415-431

Graessner T, Schenk V, Bröcker M, Mezger K (2000) Geochronological constraints on the timing of granitoid magmatism, metamorphism and post-metamorphic cooling in the Hercynian crustal cross-section of Calabria. J Metamorph Geol 18: 409-421

Guy A, Edel JB, Schulmann K, TomeK Č, LeXa O (2011) A geophysical model of the Variscan orogenic root (Bohemian Massif): implications for modern collisional orogens. Lithos 124: 144-157

Holub FV (1997a) Trace-element patterns in ultrapotassic rocks of the Bohemian Massif: implications for heterogeneity of their mantle sources. J Czech Geol Soc 42: 9

Holub FV (1997b) Ultrapotassic plutonic rocks of the durbachite series in the Bohemian Massif: petrology, geochemistry and petrogenetic interpretation. Sbor geol věd, Ložisk geol mineral 31: 5-26

Houseman G, McKenzie D, Molnar P (1981) Convective instability of a thickened boundary layer and its relevance for the thermal evolution of continental convergent belts. J Geophys Res 86: 6115-6132

Houseman G, Molnar P (2001) Mechanisms of lithospheric rejuvenation associated with continental orogeny. In: Miller JA, Holdsworth RE, Buick IS, Hand M (eds) Continental Reactivation and Reworking. Geological Society London Special Publications 184: pp 13-38

Hurai V, Paquette JL, Huraiová M, KoneČnÝ P (2010) $\mathrm{U}-\mathrm{Th}-\mathrm{Pb}$ geochronology of zircon and monazite from syenite and pincinite xenoliths in Pliocene alkali basalts of the intra-Carpathian back-arc basin. J Volcanol Geotherm Res 198: 275-287

Jackson SE, Pearson NJ, Griffin WL, Belousova EA (2004) The application of laser ablation-inductively coupled plasma-mass spectrometry to in situ U-Pb zircon geochronology. Chem Geol 211: 47-69 
Jaffrey AH, Flynn KF, Glendenin LE, Bentley WC, Essling AM (1971) Precision measurement of halflives and specific activities of ${ }^{235} \mathrm{U}$ and ${ }^{238} \mathrm{U}$. Phys Rev C4:1889-1906

Janoušek V, Holub FV, Rogers G, Bowes D (1997) Two distinct mantle sources of Hercynian magmas intruding the Moldanubian unit, Bohemian Massif, Czech Republic. J Czech Geol Soc 42: 10

JANOUŠEK V, HoLuB FV (2007) The causal link between HPHT metamorphism and ultrapotassic magmatism in collisional orogens: case study from the Moldanubian Zone of the Bohemian Massif. Proc Geol Assoc 118: 75-86

Kober B, Lippolt HJ (1985) Pre-Hercynian mantle lead transfer to basement rocks as indicated by lead isotopes of the Schwarzwald crystalline, SW-Germany. Contrib Mineral Petrol 90: 162-171

Kotková J, Leichmann J, Schaltegger U (2003) 338-335 Ma old intrusions in the E Bohemian massif - a relic of the orogen-wide durbachitic magmatism in European Variscides. J Czech Geol Soc 48: 80-81

Kotková J, Leichmann J, Schaltegger U (2010) Two types of ultrapotassic plutonic rocks in the Bohemian Massif - coeval intrusions at different crustal levels. Lithos 115: $163-176$

Kroner U, Romer RL (2013) Two plates - many subduction zones: the Variscan orogeny reconsidered. Gondwana Res 24: 298-329

Lagarde JL, Dallain C, Ledru P, Courrioux G (1994) Strain patterns within the late Variscan granitic dome of Velay, French Massif Central. J Struct Geol 16: 839-852

Lardeaux JM, Ledru P, Daniel I, Duchene S (2001) The Variscan French Massif Central - a new addition to the ultrahigh pressure metamorphic 'club': exhumation processes and geodynamic consequences. Tectonophysics 332: $143-167$

Ledru P, Courrioux G, Dallain C, Lardeaux JM, Montel JM, Vanderhaeghe O, Vitel G (2001) The Velay Dome (French Massif Central): melt generation and granite emplacement during orogenic evolution. Tectonophysics 342: 207-237

Lexa O, Schulmann K, JanouŠek V, ŠTíPská P, Guy A, RACEK M (2011) Heat sources and trigger mechanisms of exhumation of HP granulites in Variscan orogenic root. J Metamorph Geol 29: 79-102

LuDwig K (2008) User's manual for Isoplot Version 3.70, a geochronological toolkit for Microsoft Excel. Berkeley Geochronology Center Special Publications 4: 1-76

Malavieille JP, Guihot P, Costa S, Lardeaux JM, Gardien V (1990) Collapse of the thickened Variscan crust in the French Massif Central: Mont Pilat extensional shear zone and St Etienne Late Carboniferous basin. Tectonophysics 177: 139-149

Marignac C, Leroy J, Macaudiere J (1980) Tectonometamorphic evolution of a part of the Hercynian orogen - the
Cévennes médianes, French Massif Central. C R Acad Sci Paris 291: 605-608 (in French)

Martin H, Moyen JF, Rapp R (2010) Sanukitoids and the Archaean-Proterozoic boundary. Trans Roy Soc Edinb, Earth Sci 100: 15-33

Matte P (1986) Tectonics and plate-tectonics model for the Variscan Belt of Europe. Tectonophysics 126: 329-374

Melleton J, Cocherie A, Faure M, Rossi P (2010) Precambrian protoliths and Early Paleozoic magmatism in the French Massif Central: U-Pb data and the North Gondwana connection in the west European Variscan belt. Gondwana Res 17: 13-25

Mialhe J (1980) The Borne granite, petrographic geochemical and geochronological study. Unpublished $\mathrm{PhD}$ thesis, University of Clermont, pp 1-171 (in French)

MichON G (1987) Vaugnerites from eastern French Massif Central: a multivariate statistical approach on major elements. Bull Soc Géol France 3: 591-600 (in French)

Molina JF, Montero P, Bea F, Scarrow JH (2012) Anomalous xenocryst dispersion during tonalite-granodiorite crystal mush hybridization in the mid crust: mineralogical and geochemical evidence from Variscan appinites (Avila Batholith, Central Iberia). Lithos 153: 224-242

Molnar P, Houseman G (2004) The effects of buoyant crust on the gravitational instability of thickened mantle lithosphere at zones of intracontinental convergence. Geophys J Int 158: 1134-1150

Montel JM (1988) First discovery of an orthopyroxenebearing vaugnerite: petrography, geochemistry, and implications on the genesis of vaugnerites. C R Acad Sci Paris 306: 985-990 (in French)

Montel JM, AbDelghaffar R (1993) Late-migmatitic granites from the Velay (Massif Central): main petrographic and geochemical characteristics. Géol Fr 1: 15-28 (in French)

Montel JM, Weisbrod A (1986) Characteristics and evolution of "vaugneritic magmas": an analytical and experimental approach, on the example of the Cévennes Médianes (French Massif Central). Bull Minéral 109: 575-587

Montel JM, Marignac C, Barbey P, Pichavant M (1992) Thermobarometry and granite genesis - the Hercynian low-P, high-T Velay anatectic dome (French MassifCentral). J Metamorph Geol 10: 1-15

Montero P, Bea F, Zinger T, Scarrow J, Molina J, WhiteHOUSE M (2004) 55 million years of continuous anatexis in Central Iberia: single-zircon dating of the Peña Negra Complex. J Geol Soc, London 161: 255-263

Mougeot R, Respaut JP, Ledru P, Marignac C (1997) U-Pb chronology on accessory minerals of the Velay anatectic dome (French Massif Central). Eur J Mineral 9: 141-156

Murphy JB (2013) Appinite suites: a record of the role of water in the genesis, transport, emplacement and crystallization of magma. Earth Sci Rev 119: 35-59 
PaLm QA (1957) Crystalline rocks from the Cévennes médianes, near Largentière, Ardèche, France. Unpublished PhD thesis, University of Utrecht, pp 1-121 (in French)

Paquette JL, Monchoux P, Couturier M (1995) Geochemical and isotopic study of a norite-eclogite transition in the European Variscan belt: implications for $\mathrm{U}-\mathrm{Pb}$ zircon systematics in metabasic rocks. Geochim Cosmochim Acta 59: 1611-1622

Perini G, Cebria J, LóPez-Ruiz J, Doblas M (2004) Carboniferous-Permian mafic magmatism in the Variscan belt of Spain and France: implications for mantle sources. In: Wilson M, Neumann ER, Davies GR, Timmerman MJ, Heeremans M, Larsen BT (eds) Permo-Carboniferous Magmatism and Rifting in Europe. Geological Society London Special Publications 223: pp 415-438

Pin C, LANCELOT J (1982) U-Pb dating of an early Paleozoic bimodal magmatism in the French Massif Central and of its further metamorphic evolution. Contrib Mineral Petrol 79: 1-12

Pin C, Marini F (1993) Early Ordovician continental break-up in Variscan Europe: $\mathrm{Nd}-\mathrm{Sr}$ isotope and trace element evidence from bimodal igneous associations of the Southern Massif Central, France. Lithos 29: 177-196

R'Kha Chaham K, Couturié JP, Duthou JL, Fernandez A, Vitel G (1990) The Fix augen gneiss (French MassifCentral): a new evidence for the lower Cambrian peraluminous magmatism. C R Acad Sci Paris 311: 845-850 (in French)

Rey P, Vanderhaeghe O, Teyssier C (2001) Gravitational collapse of the continental crust : definition, regimes and modes. Tectonophysics 342: 435-449

Roger F, Respaut JP, Brunel M, Matte P, Paquette JL (2004) U-Pb dating of Augen orthogneisses from the Axial Zone of the Montagne Noire (southern of Massif Central): new witness of Ordovician magmatism into the Variscan Belt. C R Geosci 336: 19-28

Rosenberg CL (2001) Deformation of partially molten granite: a review and comparison of experimental and natural case studies. Int J Earth Sci 90: 60-76

SABAtier H (1980) Vaugnérites and granites, a peculiar association of basic and acid rocks. Bull Minéral 103: 507-522

SABATIER H (1991) Vaugnerites: special lamprophyrederived mafic enclaves in some Hercynian granites from Western and Central Europe. In: Didier J, BARBARIN B (eds) Enclaves and Granite Petrology. Elsevier, Amsterdam, pp 63-81

Scarrow JH, Bea F, Montero P, Molina J (2008) Shoshonites, vaugnerites and potassic lamprophyres: similarities and differences between 'ultra'-high-K rocks. Trans Roy Soc Edinb, Earth Sci 99: 159-175

Scarrow JH, Molina J, Bea F, Montero P (2009) Withinplate calc-alkaline rocks: insights from alkaline mafic magma - peraluminous crustal melt hybrid appinites of the Central Iberian Variscan continental collision. Lithos 110: 50-64

Scarrow JH, Molina JF, Bea F, Montero P, Vaughan APM (2011) Lamprophyre dikes as tectonic markers of late orogenic transtension timing and kinematics: a case study from the Central Iberian Zone. Tectonics 30: TC4007

SCHENK V (1990) The exposed crustal cross section of southern Calabria, Italy: structure and evolution of a segment of Hercynian crust. In: Salisbury MH, Fountain DM (eds) Exposed Cross-Sections of the Continental Crust. Springer, New York, pp 21-42

Schmidt C, Rickers K, Wirth R, Nasdala L, Hanchar JM (2006) Low-temperature Zr mobility: an in situ synchrotron-radiation XRF study of the effect of radiation damage in zircon on the element release in $\mathrm{H}_{2} \mathrm{O}+\mathrm{HCl} \pm$ $\mathrm{SiO}_{2}$ fluids. Amer Miner 91: 1211-1215

Tera F, Wasserburg G (1972) U-Th-Pb systematics in three Apollo 14 basalts and the problem of initial $\mathrm{Pb}$ in lunar rocks. Earth Planet Sci Lett 14: 281-304

vAN DE ZedDe DMA, Wortel MJR (2001) Shallow slab detachment as a transient source of heat at midlithospheric depths. Tectonics 20: 868-882

VANDERHAEghe O, TEyssier C (2001) Crustal-scale rheological transitions during late-orogenic collapse. Tectonophysics 335: 211-228

VANDERHAEGHE O (2009) Migmatites, granites and orogeny: flow modes of partially-molten rocks and magmas associated with melt/solid segregation in orogenic belts. Tectonophysics 477: 119-134

Vigneresse JL, BuRg JP (2004) Strain-rate dependent rheology of partially molten rocks. In: GrocotT J, McCAFfrey KJW, Taylor G, Tikoff B (eds) Vertical Coupling and Decoupling in the Lithosphere. Geological Society London Special Publications 227: pp 327-336

Vigneresse JL, Burg JP, Moyen JF (2008) Instabilities development in partially molten rocks. Boll Soc geol ital 127: 235-242

von Raumer JF, Stampfli GM, Bussy F (2003) Gondwanaderived microcontinents - the constituents of the Variscan and Alpine collisional orogens. Tectonophysics 365: 7-22

WeIsBrod A (1970) Petrology of the metamorphic basement in the Cévennes Médianes (French Massif Central): sedimentological reconstruction and thermodynamic study of metamorphism. Unpublished thesis, University of Nancy, pp 1-244

Williamson BJ, Downes H, Thirlwall MF (1992) The relationship between crustal magmatic underplating and granite genesis - an example from the Velay granite complex, Massif Central, France. Trans Roy Soc Edinb, Earth Sci 83: 235-245 